Iran Journal of Nursing (IJN)

Vol 32, No. 118, Jun 2019: 78- 92

\title{
Effects of Smartphone-based Nutritional Education on the Biochemical Indicators of Patients with Ileostomy
}

\author{
Alice Khachian ${ }^{1}$, Mohamad Sadaegh Fazeli ${ }^{2}{ }^{\text {Hadice }}$ Sabour $^{3}$, Hamid Haghani ${ }^{4}$, \\ GHazaleh Akhoondian ${ }^{5}$
}

\begin{abstract}
Background \& Aims: Ileostomy is a surgically made opening that connects the ileum to the abdominal wall after gastrointestinal surgeries to help the improvement and eliminate inflammations in the part of the intestine that has undergone an anastomosis. The type of diet and eating habits change following losing the normal defecation path after ostomy surgery of the bowel. The stool should start draining from the stoma about 72 hours after surgery. Early high output from an ileostomy is common and attention should be paid to the input and output fluids in order to maintain a balanced electrolyte level in the patient. Given the output of liquid or semi-liquid effluent from the stoma, it is possible to detect fluid and electrolyte abnormalities, decreased absorption of fats, vitamins, calories and minerals, and malnutrition in the patient. Therefore, patients who undergo ileostomy need to learn the proper nutritional management method using novel techniques. One of the uses of smartphones is teaching proper, rational, and principled nutrition to patients. However, this type of education should be continuous and be applied for a long time. Results have shown that education via smartphones can improve education to patients, prevention of diseases, and decrease medical costs. In addition, apps installed on smartphones are a new way to present information to patients to eliminate barriers to learning and increase participation in health education courses. Different types of social media (e.g., private and smartphones) are common in the fact that they are audience-centered, are always available to the person, and their content is produced by people, which can play an important role in transferring knowledge and information to the person. This study aimed to determine the effect of smartphone-based nutrition training on biochemical indicators of patients undergoing ileostomy.

Materials \& Methods: This quasi-experimental clinical trial was performed with a control group on 72 patients aged 18-60 years undergoing ileostomy in 2018. Sampling was carried out continuously for five months due to the fact that the research was limited to one center and there was a limited number of clients. The participants were divided into two control and test groups by the non-random allocation method. It is notable that the first 36 people were assigned to the control group and the rest were assigned to the test group to prevent information leakage. Both groups received routine nutrition education provided by the personnel of the ward following undergoing ileostomy. In addition to this training, the subjects in the test group received education by the researcher using smartphones on the third and fifth days before discharge. First, the app was installed and used in the education sessions. This was an android app written with Java programming language and 2.1.4 android, provided to patients offline, and included four main parts; "what is an ileostomy?", "what to eat? What not to eat?", "body mass index (BMI)?", and "fluid balance". Data were collected using demographic characteristics and biochemical indexes (white blood cells, total lymphocyte count, hemoglobin,
\end{abstract}

\footnotetext{
1. Assistant Professor, Department of Internal-Surgical Nursing, School of Nursing and Midwifery, Iran University of Medical Sciences, Tehran, Iran

2. Professor, Department of General Surgery, Imam Khomeini Hospital Complex, Tehran University of Medical Sciences, Tehran, Iran

${ }^{3}$. Assistant Professor, Department of Nutrition, Imam Khomeini Hospital Complex, Tehran University of Medical Sciences, Tehran, Iran

4. Lecturer, Department of Biostatistics, School of Health, Iran University of Medical Sciences, Tehran, Iran

5. MS in Internal-Surgical Nursing, School of Nursing and Midwifery, Iran University of Medical Sciences, Tehran, Iran (Corresponding author) Tel: $09124190344 \quad$ Email: akhondian.gh@tak.iums.ac.ir
} 
albumin, transferrin, C-reactive protein, and serum total protein) questionnaire. In addition, the biochemical indexes were assessed in two stages; one day before ileostomy in the hospital and three weeks after the surgery on the day of visit to the clinic by bloodletting from peripheral blood vessels of patients. In total, three ccs of blood were collected from each patient, $0.5 \mathrm{ccs}$ of which was poured into a test tube containing K3 ethylenediaminetetraacetic acid (EDTA) anticoagulant to check the complete blood count (CBC) and 2.5 ccs was collected in a normal test tube with no anticoagulant to collect serum and perform blood clotting process for biochemical tests. Data analysis was performed in SPSS version 16 using descriptive (frequency distribution tables and numerical indexes) and inferential (Chi-square, Fisher's exact test, independent t-test, and analysis of variance) statistics. In addition, a P-value of 0.05 was considered statistically significant.

Results: In total, 12 subjects were excluded from the research and 30 participants per group were assessed. The majority of the participants were male and married, had a diploma degree, no history of drug use, an acceptable economic status, living in urban areas, and in the age range of 51-60 years. In addition, more than two-thirds of the patients were diagnosed with rectum cancer and had a history of chemotherapy and radiotherapy before the surgery. There was no significant difference between the groups regarding biochemical indexes before ileostomy. Nevertheless, a significant difference was observed between the groups three weeks after the surgery only in terms of the CRP index. In this regard, the CRP index was significantly higher, compared to the test group. The changes in the indexes of the two groups demonstrated an increase in albumin and total protein indices in the test group, compared to the control group, and an increase in the CRP index of the control group.

Conclusion: While changes in the biochemical indexes of the participants were significant, they were clinically insignificant, and we could not express that using smartphones for nutrition education improved biochemical indexes in patients undergoing ileostomy. Therefore, it is recommended that training be carried out for longer periods, and patients with rectum cancer be assessed separately in the fourth week after ileostomy due to the onset of chemotherapy. In addition, it is suggested that further studies be conducted on larger populations to make the final decisions about the applicability of this type of training. By doing so, an important step would be taken toward improving the biochemical indexes of patients.

Keywords: Nutritional Education, Smartphone, Biochemical Indicators, Ileostomy

\section{Conflict of Interest: No}

How to Cite: Khachian A, Fazeli MS, Sabour H, Haghani H, Akhondian Gh. Effects of Smartphone-based Nutritional Education on the Biochemical Indicators of Patients with Ileostomy. Iran Journal of Nursing. 2019; 32(118):78-92.

Received: 16 March 2019

Accepted: 19 Jun 2019 


\title{
تأثير آموزش تغذيه مبتنى بر كوشى هوشمند بر شاخصهاى بيوشيميايى افراد داراى

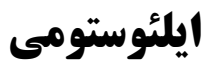

\author{
آليس خاجِيان '، محمد صادق فاضلى '، حديث صبورّ'، حميد حقانى ، غزاله آخونديان
}

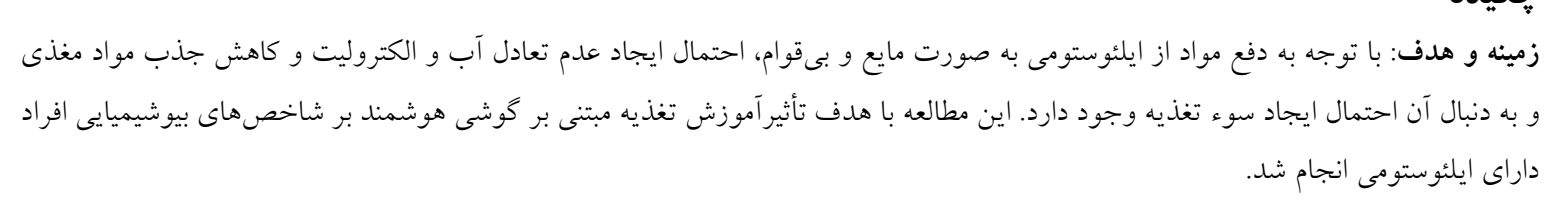

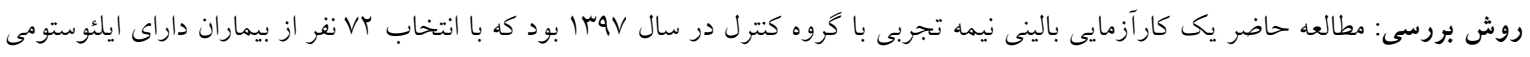

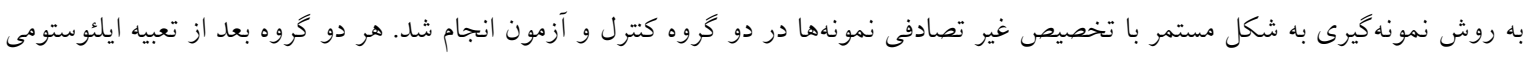

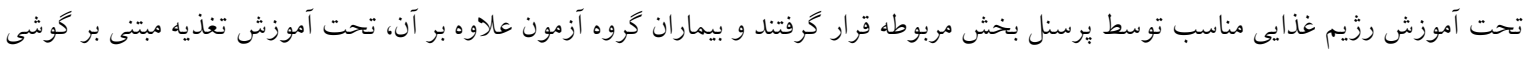

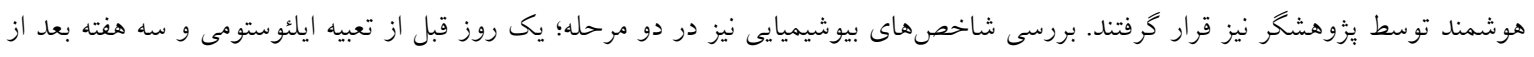

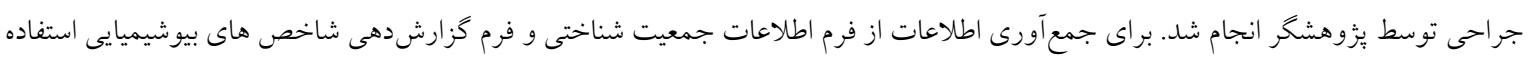

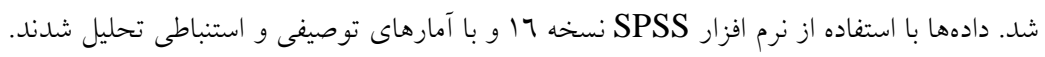

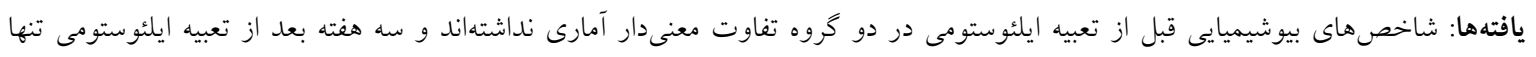

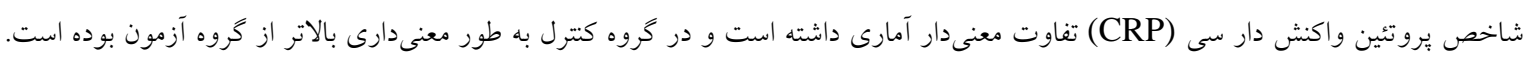

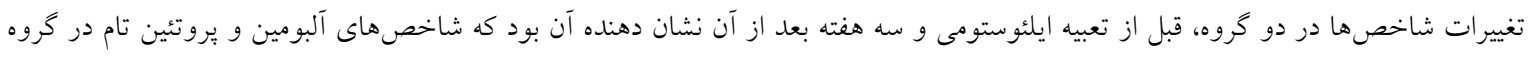

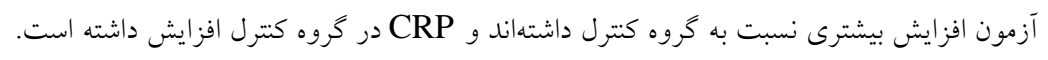

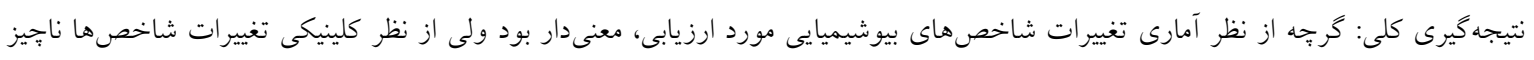

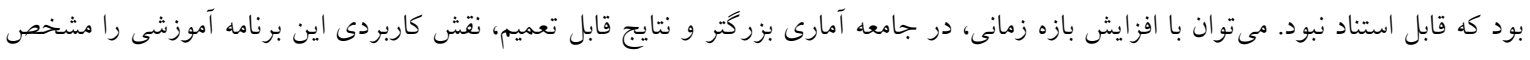
كرد تا براى بيمار ان داراى ايلئوستومى قابل استفاده كردد.

كليد وازهها: آموزش تغذيه، گوشى هوشمند، شاخصهاى بيوشيميايى، ايلئوستومى تعارض منافع: ندارد تاريخ دريافت:

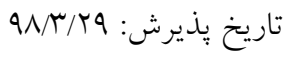

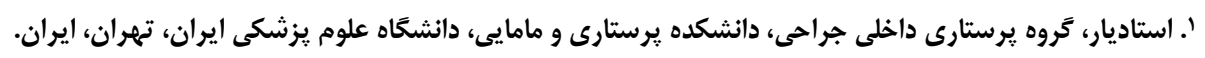

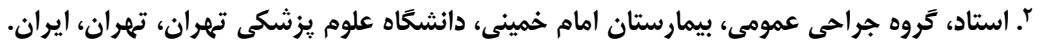

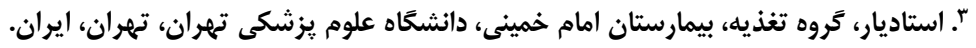

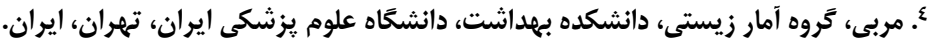

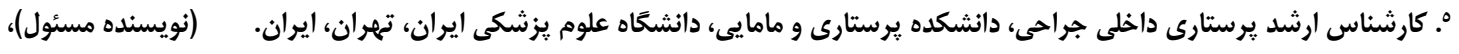

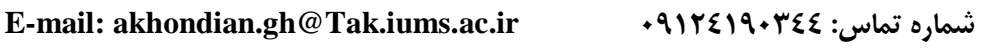


لنفوسيت ها و كلبولهاى سفيد خون و يروتئين تام خون

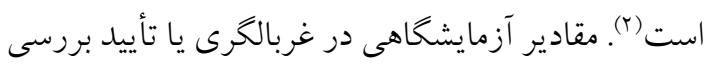

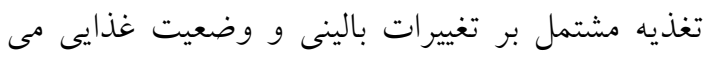
تو اند سودمند باشد (r). از آنجايى كه اين بيماران مقدار زيادى مايع رادر باتس مراحل اوليه بعد از عمل از دست مىدهند، لازم است ميزان

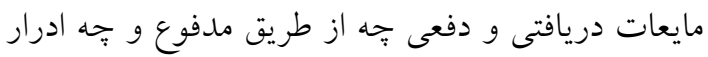
به دقت اندازه كيرى و ثبت شود تا نياز بيمار به مايعات رفع شود. با اين مقدار دفع مايع، سديم و يتاسيم نيز از دست مىرود"). با مصرف نكردن غذا، برون ده استوما

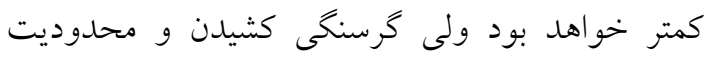
استفاده از مايعات براى كاهش برونده استوما، اقدام بسيار خطرناكى است (r). با ارائه آموزش جهت مصرف مايعات و سديم به اندازه كافى در بيماران داراى ايلئوستومى، مىتوان از بروز

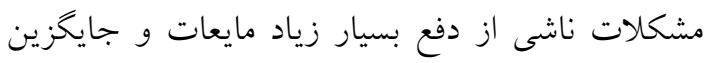

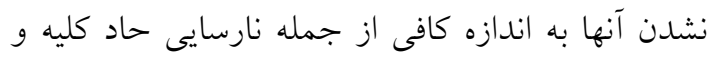

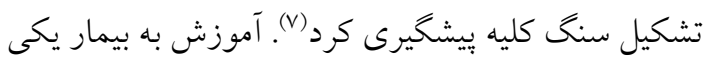

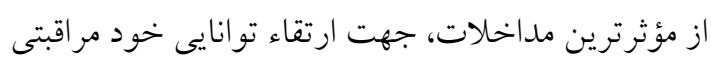

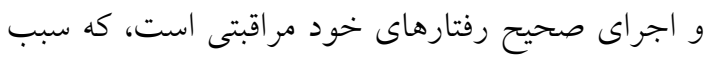

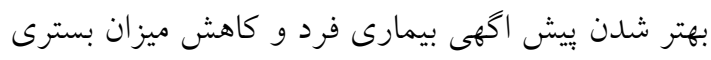

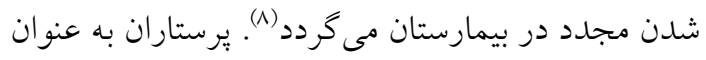
يكى از اجزاى كليدى در سيستمهاى بهداشتى درمانى،

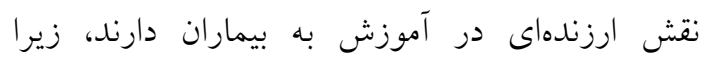
دسترسى بيشترى به بيمار و خانو اده وى داشته و زمان زيادى را صرف مراقبت مى كنند. در نتيجه فرصتهاى

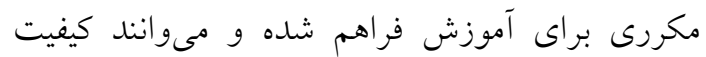

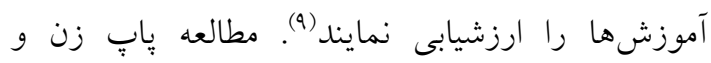

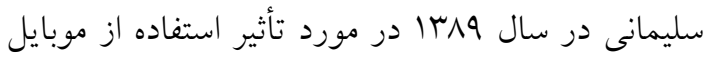
بر آموزش نشان داد با وجود اينكه هر دو روش آموزش سخنرانى و آموزش از طريق تلفن همراه بر يادگيرى

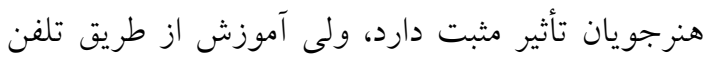
همراه نسبت به آموزش از طريق سخنرانى تأثير بيشترى

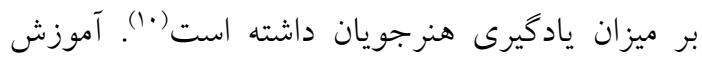

\section{مقدمه}

تعبيه ايلئوستومى روشى رايج بعد از برداشتن كل كولون

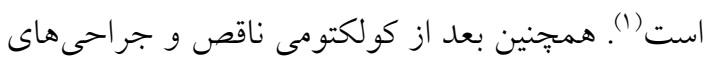

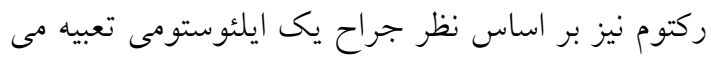

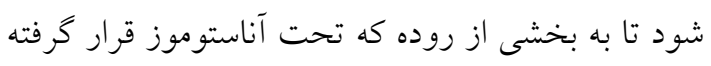

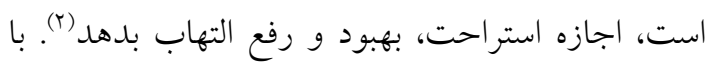

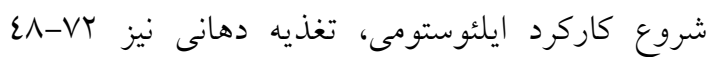

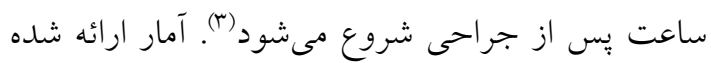

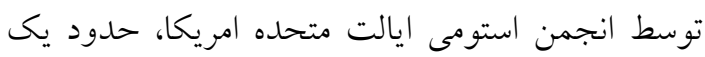

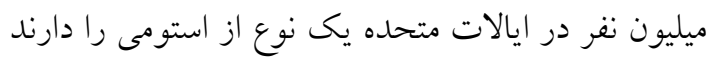
و سالانه بيش از •rا هزار جراحى تعبيه استومى در

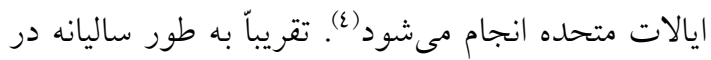
بريتانيا 9 هزار مورد ايلئوستومى انجام شده است" (1). به نقل از انجمن استومى ايران، دادههاى دقيقى از تعداد بيماران استومى در ايران وجود ندارد، اما تعداد استوميت

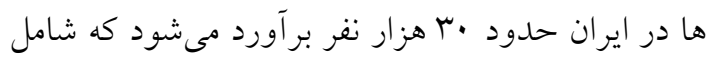

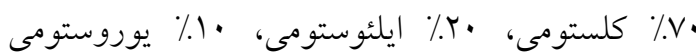

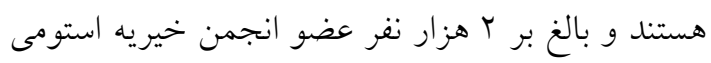

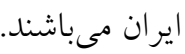
كاهش تغذيه در بيماران داراى ايلئوستومى به علت از

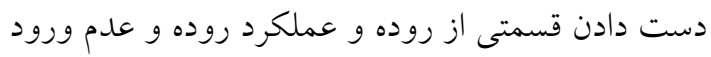

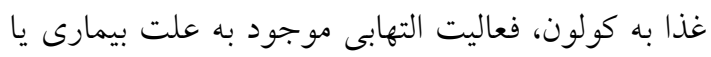

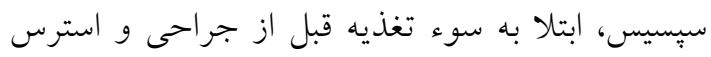

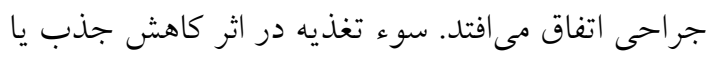

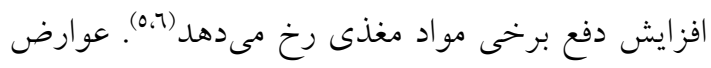

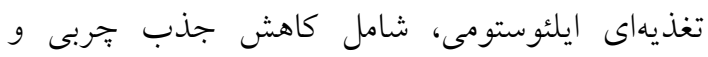

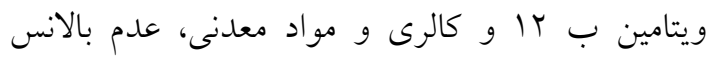
الكتروليتها، انسداد يا اسهال است. شر ايطى ماندا اسهال

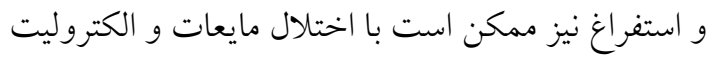

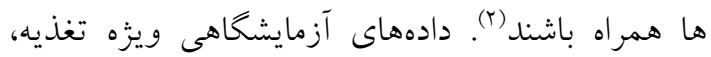
اطلاعاتى را در خصوص وضعيت تغذيهاى فرد مىدهند، از جمله اين دادها، شاخصهاى بيوشيميايى همجيون

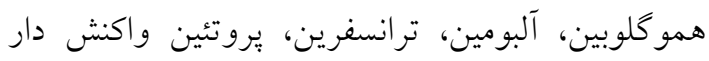
سى (c-reactive protein=CRP)، تعداد كل فين فرين 
همراه در كشورهاى در حال توسعه وجود ندارد، بنابر اين نياز است يزوهشهاى آتى به سنجش اثربخشى و كاربرد

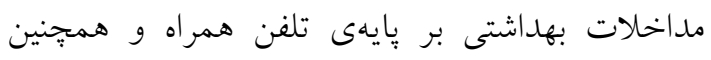

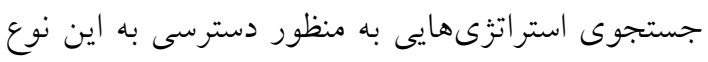

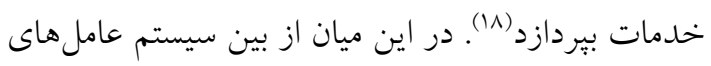

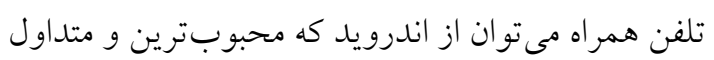

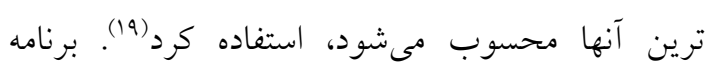

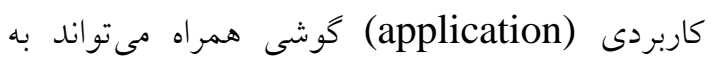
عنوان راه جديد و نوينى براى ارائه اطلاعات و در افز ايش همره دانش و آكاهى آنها استفاده نمود (·r). بر اساس دانش محقق هيج كونه مطالعه مشابهى جهت

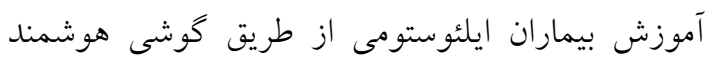

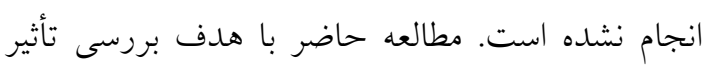

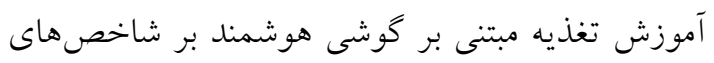

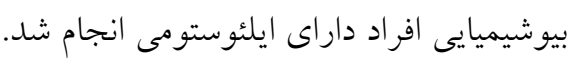

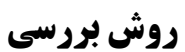

اين مطالعه كارآزمايى بالينى نيمه تجربى با كروه كنترل

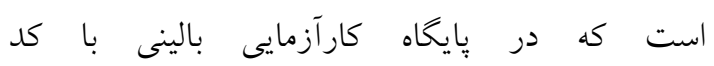
IRCT20180615040106N1 آموزش تغذيه مبتنى بر كوشى هوشمند بر شاخصهاى

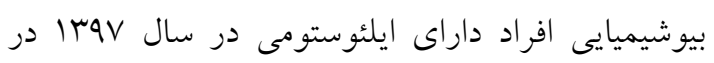
بخش جراحى بيمارستان امام خمينى (ره) شهر تهران

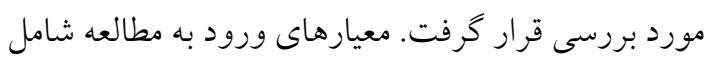
نداشتن رزيم غذايى خاص در رابطه با بيمارى زمينهاى، از جمله رزيم ديابتى، كم نمك و كم تجربى، داشتن

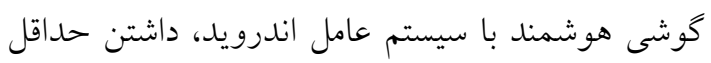

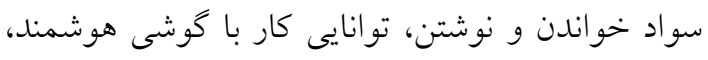

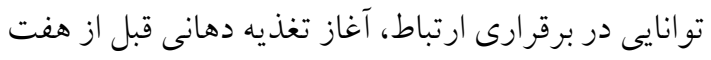

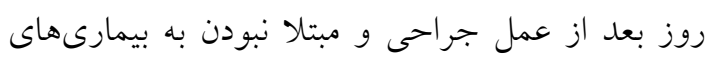

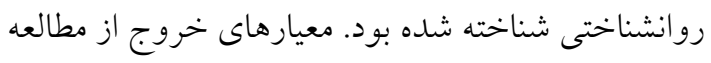

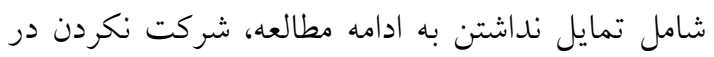
يكى جلسه آموزش، بسترى مجدد، طولانى شدن زمان بهان بسترى بيشتر از هفت روز در بيمارستان به دلايل بهتيل
تغذيه بايد بيوسته باشد و در طولانى مدت اعمال شود در

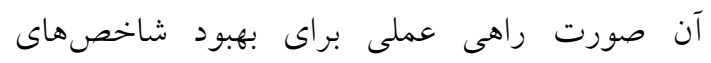

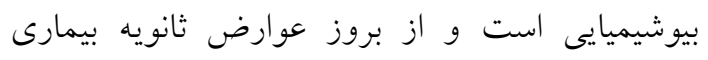
بيشخيرى مى كند (11). يّيشرفت در فناورى اطلاعات و ارتباطات، اجراى مداخلات مناسب در مراقبتهاى بهداشتى را به منظور

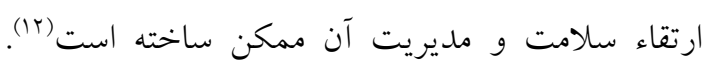

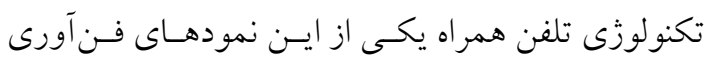

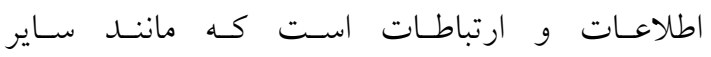
تكنولوزىهاى ارتباطى به حوزه آموزش راه يافته و باعث

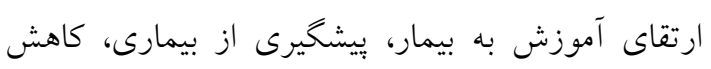

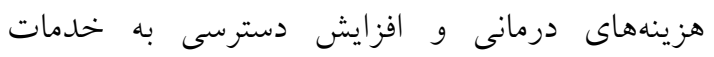

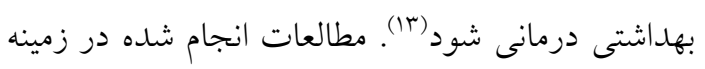

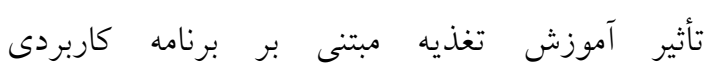
كوشى هوشمند بر برخى بيمارىهاى (application)

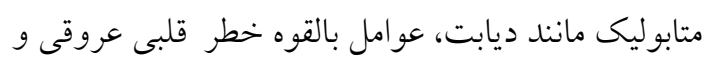

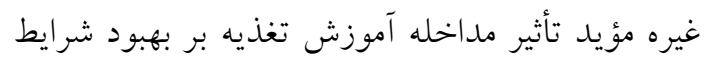

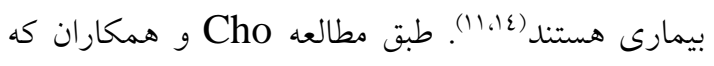

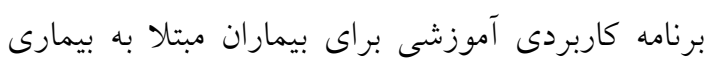

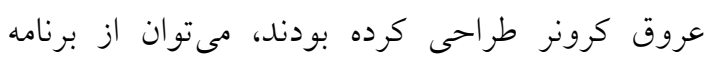

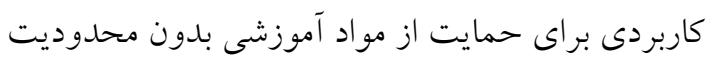

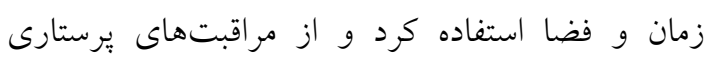

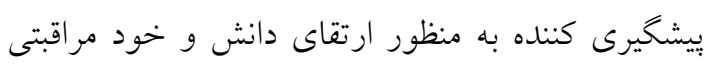

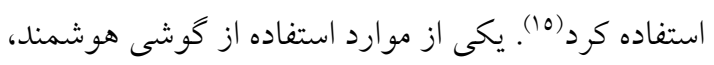
آموزش براى تغذيه درست، منطقى و اصولى بيماران

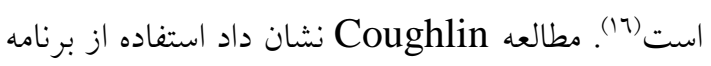
هاى كوشى هاى هوشمند با بيروى از رزيم غذايى بهتر

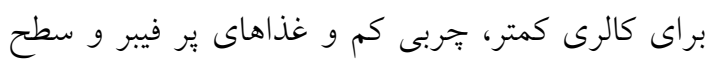

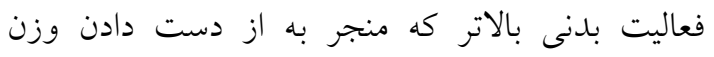

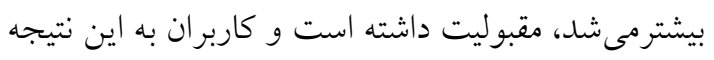
رسيدند كه برنامههاى گوشى هاى هوشمند، يكى مداخله

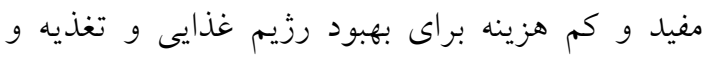

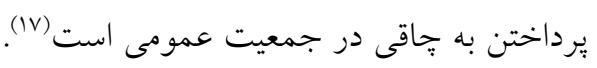
شواهد زيادى در مورد مداخلات بهداشتى بر بايهى تلفن بمديت 
بيوشيميايى شامل ميزان كَلبولهاى سفيد خون، تعداد كل

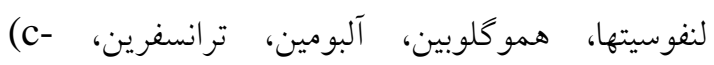
CRP reactive protein) اين شاخصها در دو مرحله اندازه گيرى شدند، مرحله

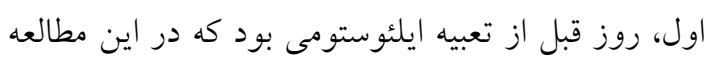

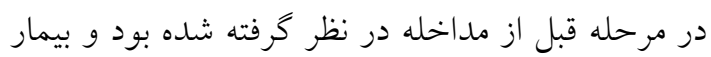
در بيمارستان حضور دارد و مرحله دوم، سه هفته بعد از

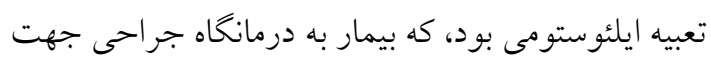

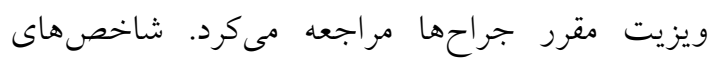

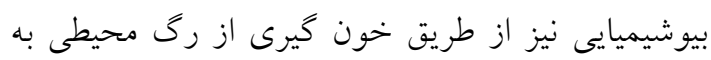

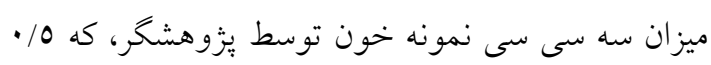
سى سى خون در لوله آزمايش حاوى ضد اند انعقاد اتيلن دى آمين تترا استيك اسيد

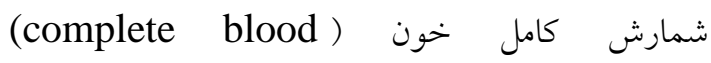
و و count=CBC

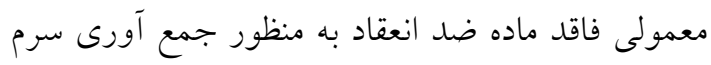

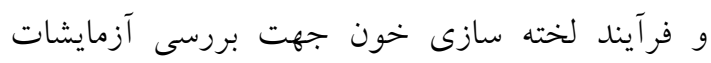

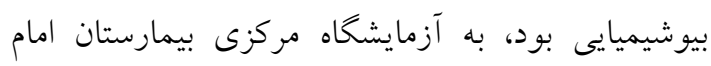

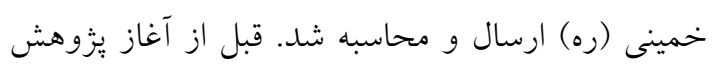

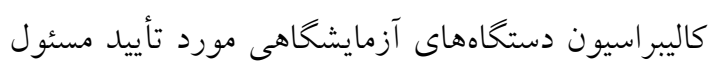

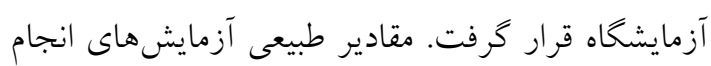

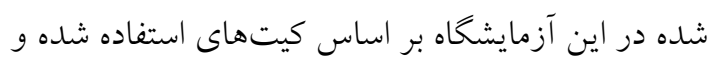

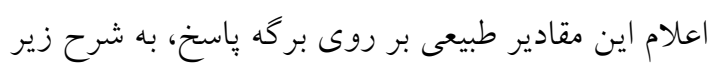

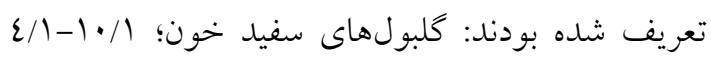

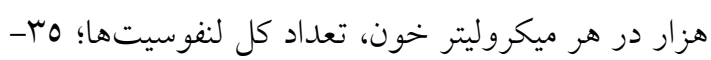

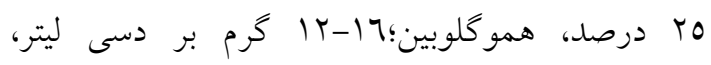

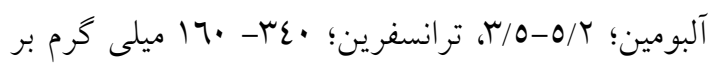

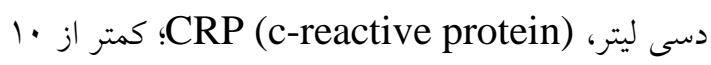

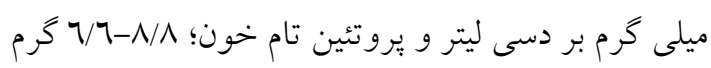
بر دسى ليتر.

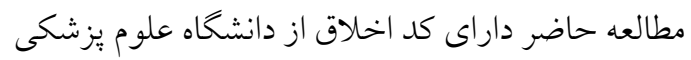

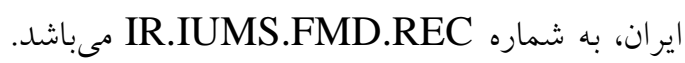

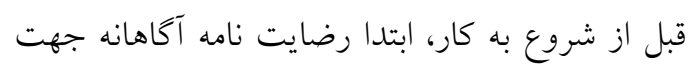

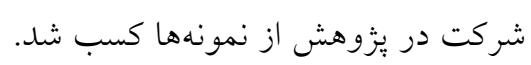

مشكلات ايجاد شده در حين جراحى (بيماران طبق روتين بخش و با صلاحديد جراح مربوطه تا هفت روز

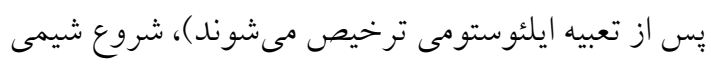

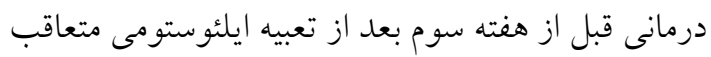
سرطان در بيماران بود. حجم نمونه در هر يك از گروهها ·ب نفر تعيين كرديد

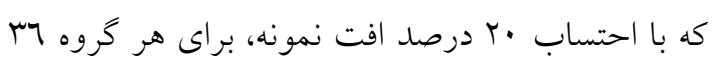

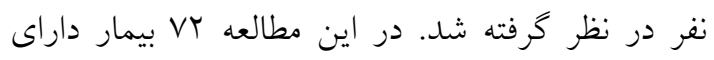

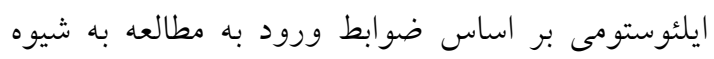
مستمر انتخاب و به روش تخصيص غير تصادفى نمونه

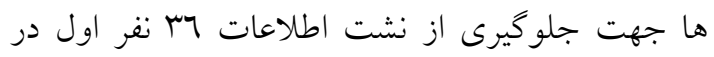

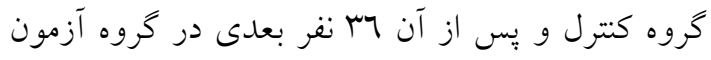

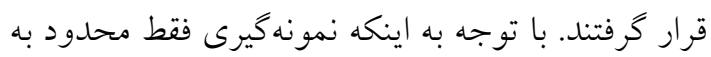

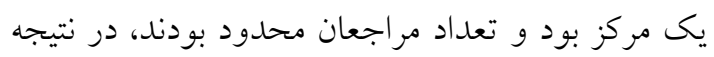

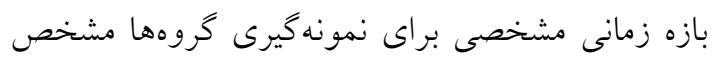

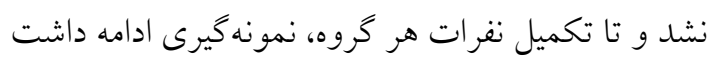
كه ينج ماه به طول انجاميد.

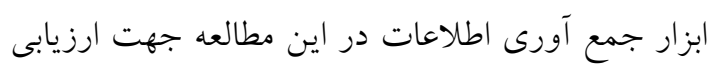

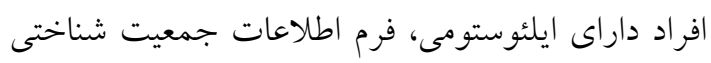

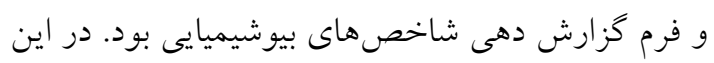

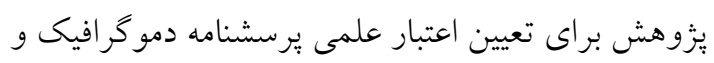

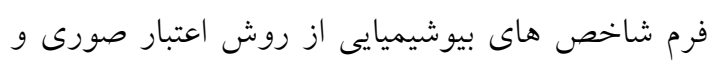

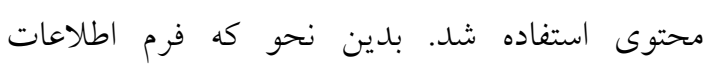
دمو گر افيك و فرم شاخص هاى بيوشيميايى را تنظيم و در

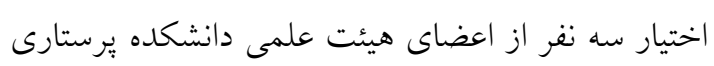

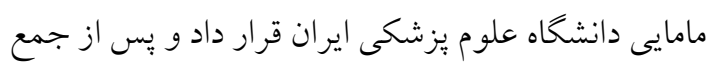

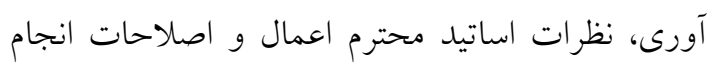
شد. در فرم اطلاعات جمعيت شناختى متغيرهاى سن، جنسيت، وضعيت تأهل، سطح تحصيلات، ميزان درآمد اقتصادى و محل زندگى، علت تعبيه ايلئوستومى، درمان

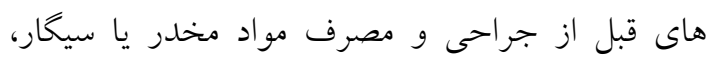

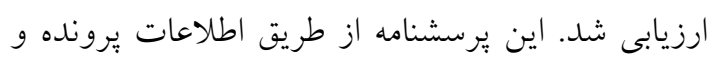

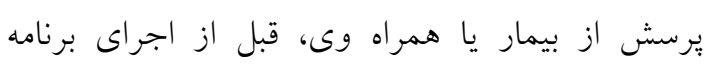

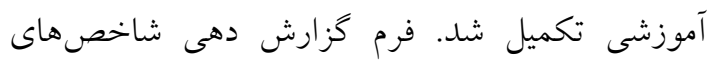


بودن و قابليت استفاده از آن بررسى شد و نظرات و

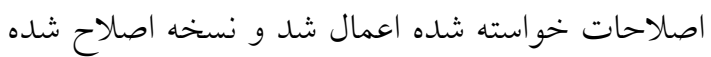
برنامه آموزشى بر روى تلفن همراه افراد كروه آزمون

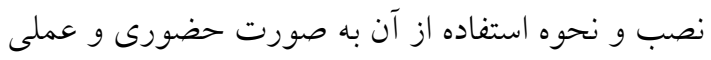

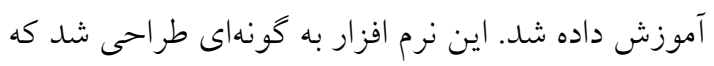
كاربر جهت دانلود برنامه، نيازى به اتصال به اينترنت

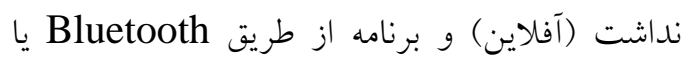
SHAREit

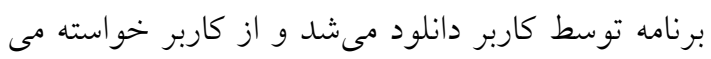

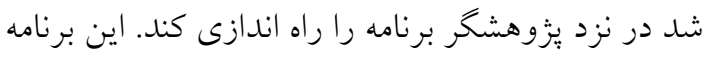

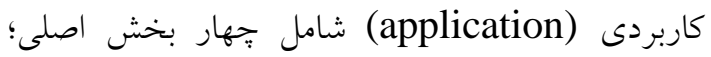

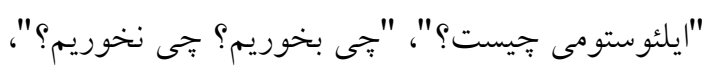

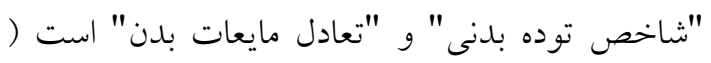

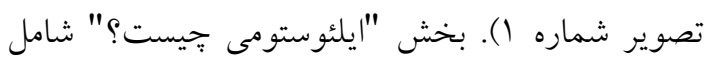

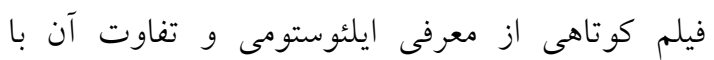

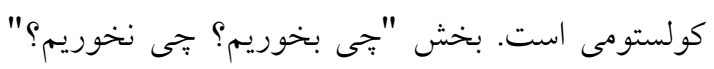

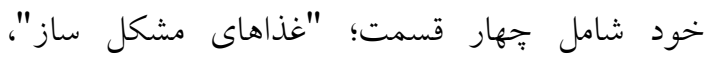
"غذاهاى ايمن"، "هشدارها و توصيه ها" و "جنند نمونه

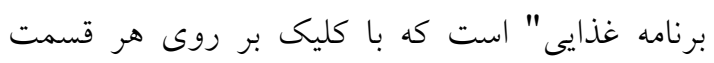

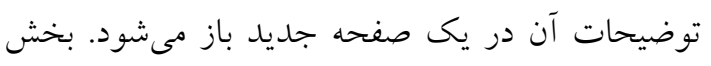

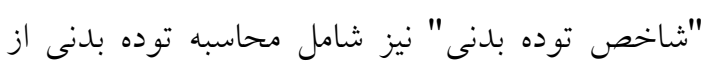

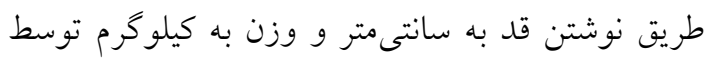

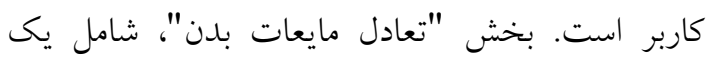

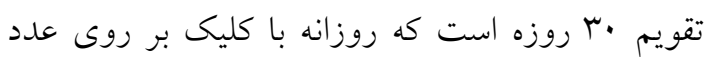

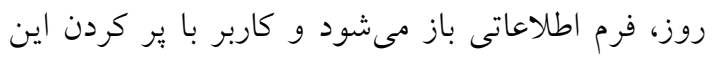

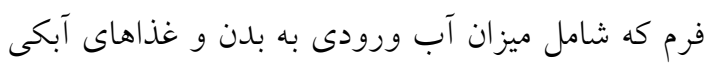

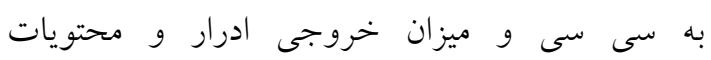
ايلئوستومى به سى سى و انتخاب ميزان تعريق به مقدارهاى تعريف شده؛ كم، متوسط و زياد و فشار دادن

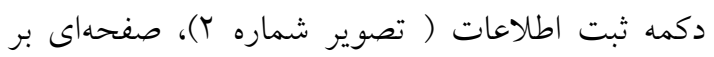

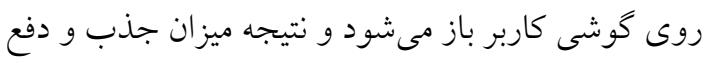
مواد مصرفى كاربر در آن روز مشخص مىشود. در

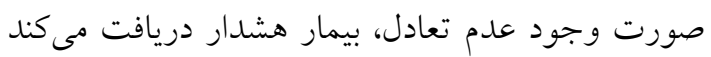
و راهنمايى مى شود (تصوير شماره ؟).
بيماران در گروه كنترل تحت آموزش رايج نحوه تغذيه و رزيم غذايى مناسب توسط يُرسنل بخش مربوطه كه شامل

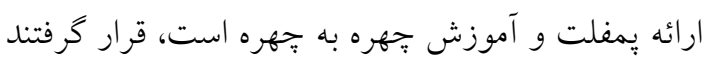

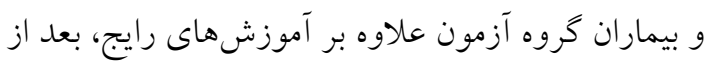

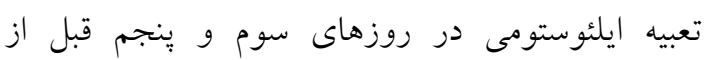
ترخيص تحت آموزش تغذيه مبتنى بر كوشى هوشمند روند

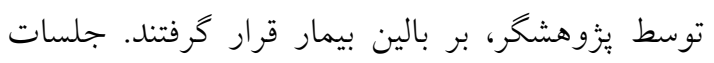

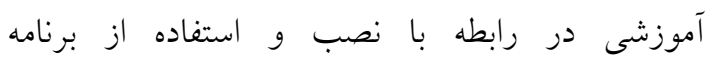

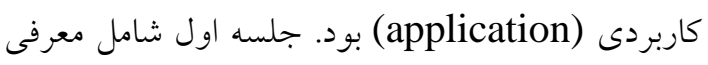

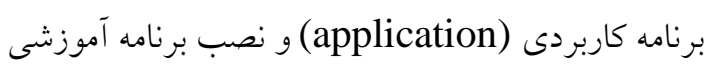
بر روى كوشى هوشمند بيمار يا خانواده وى بود، در بر بردي

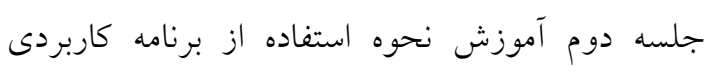

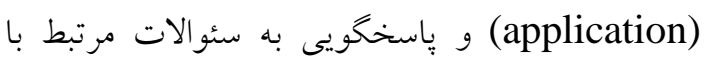

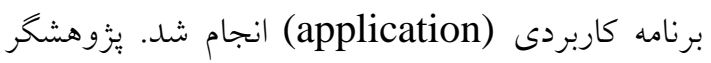

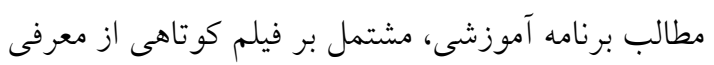

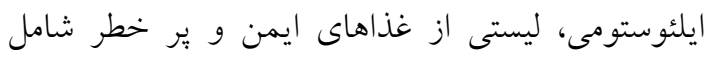

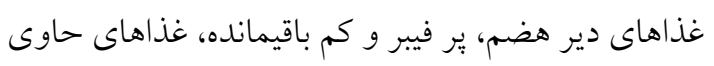

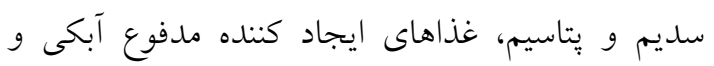

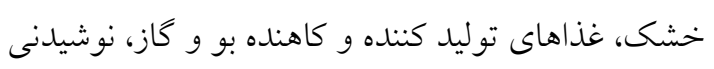

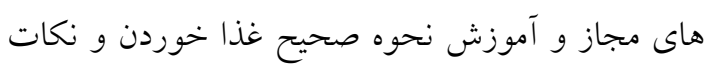

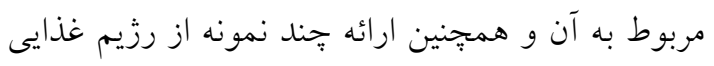

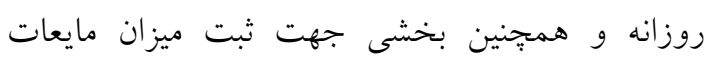
مصرفى و برون ده ادرارى و ايلئوستومى توسط كاربر را

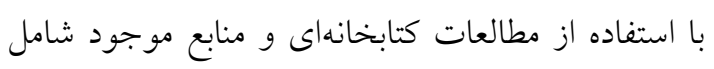

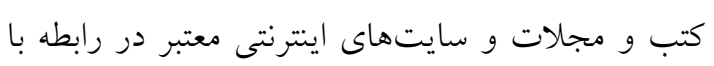

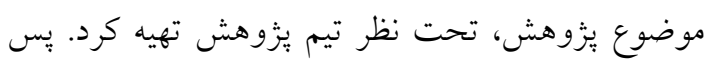

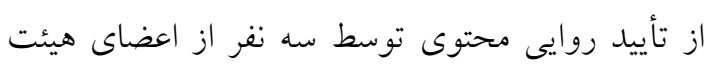

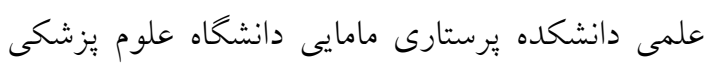

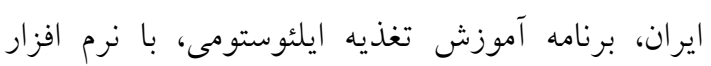
android studio مبتنى بر سيستم عامل اندرويد با زبان إنسان

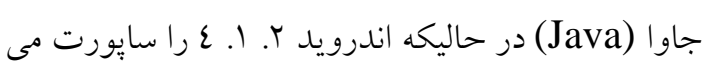

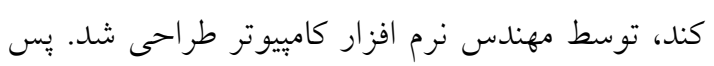

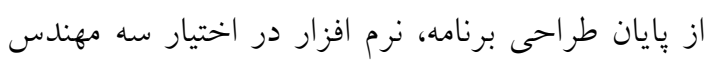
برنامه نويسى قرار گرفت، اعتبارسنجى شد و كاربردى برى 


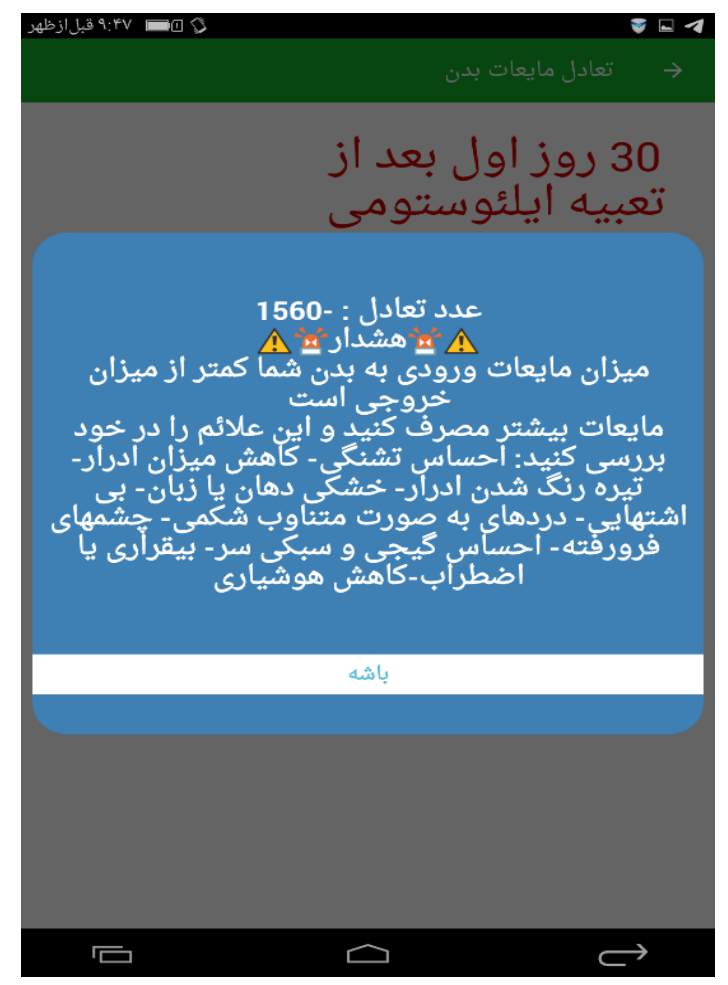

تصوير شماره "ّ: نمونه اى از نتيجه ميزان جذب و دفع

دادها با استفاده از نرم افزار SPSS نسخه 17 و بار

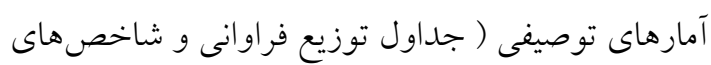

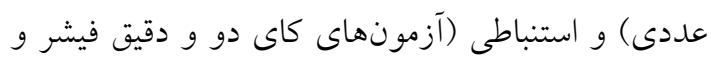

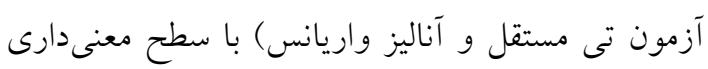

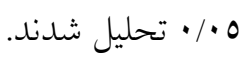

\section{يافتهها}

در طول مطالعه، در گروه كتترل دو نفر به علت بسترى

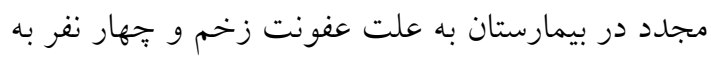

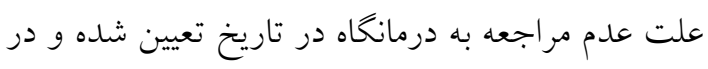

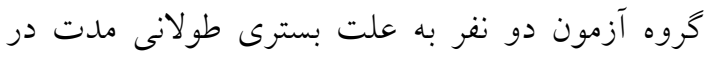

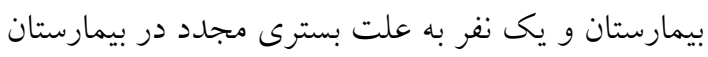

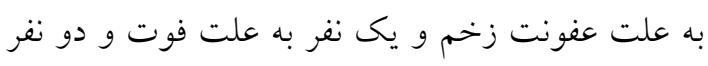
به علت عدم تمايل به ادامه همكارى (مجموعاً با با نفر)

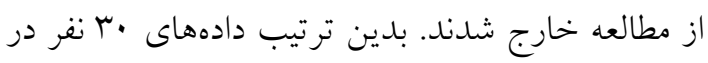
هر دو كروه مورد تحليل قرار كرفتند.

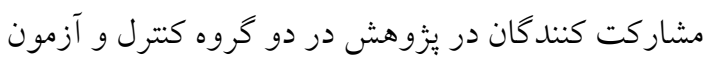
از نظر متغيرهاى جنسيت، سن، وضعيت تأهل، ميزان

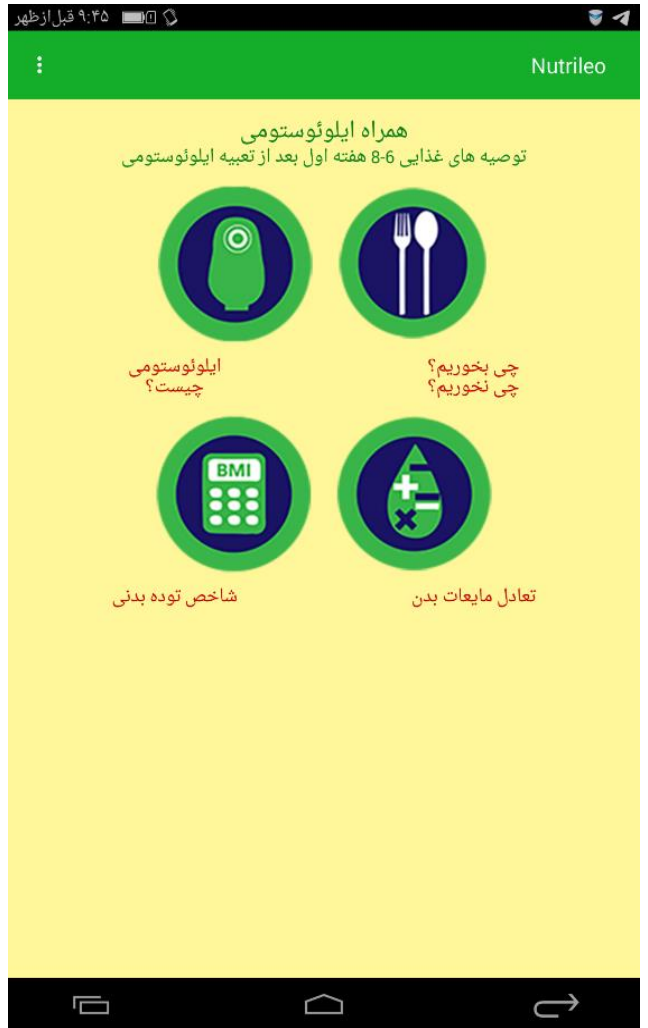

تصوير شماره (: بخشهاى اصلى برنامه كاربردى

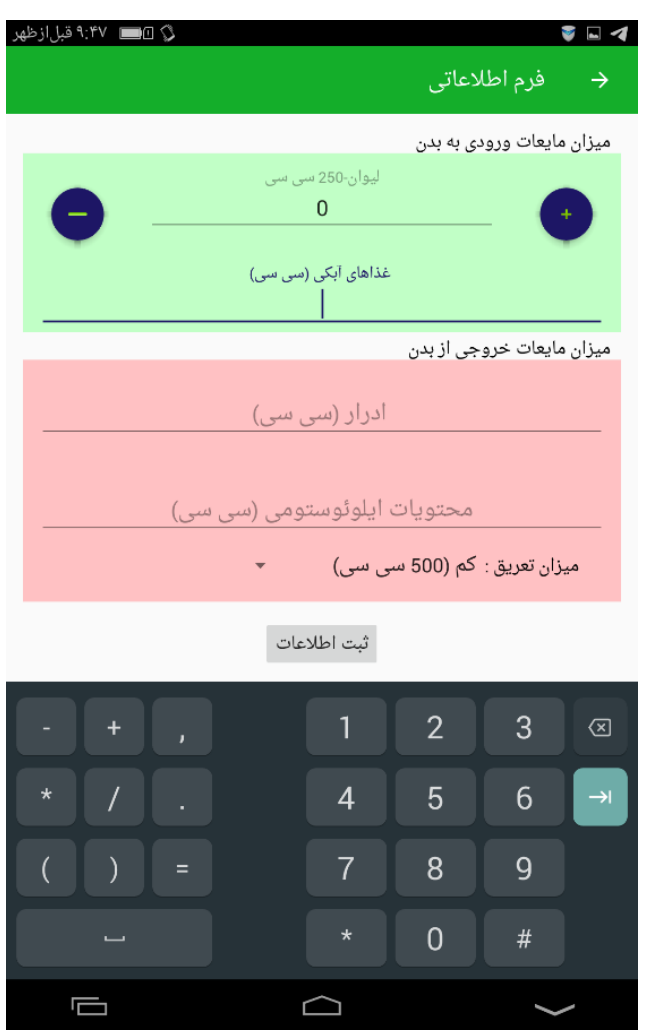

تصوير شماره ז: فرم اطلاعاتى جذب و دفع 
مخدر و داراى وضعيت اقتصادى خوب و شهرنشين و در دامنهى سنى •7-10 سال قرار داشتند. بيش از دو سوم بيمار ان داراى ايلئوستومى، مبتلا به سرطان ركتوم بودهاند و سابقه شيمى درمانى و راديوترايى قبل از جراحى داشته اند (جدول شماره (1).
تحصيلات، وضعيت اقتصادى، محل سكونت، سابقه مصرف مواد مخدر يا سيخار، درمانهاى قبل از جراحى و علت تعبيه ايلئوستومى، تفاوت آمارى معنىدار نداشته و همخن بودند. بيشتر نمونهاى مورد يزوهش در هر دو كروه مرد و متأهل، دييلمه و بدون سابقهى مصرف مواد

\begin{tabular}{|c|c|c|c|c|}
\hline \multicolumn{5}{|c|}{ جدول شماره ا: مشخصات جمعيت شناختى بيماران داراى ايلئوستومى } \\
\hline نتيجه آزمون & 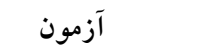 & 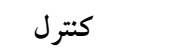 & كروه & \multirow{3}{*}{ متغير } \\
\hline & $n=r$. & $n=r$. & & \\
\hline & تعداد (درصد) & تعداد (درصد) & & \\
\hline نتيجه آزمون كاى د : & $(r \cdot / \cdot) q$ & $(Y T / V) \wedge$ & زن & \multirow{4}{*}{ جنسيت } \\
\hline$X^{2}=\cdot / \cdot \wedge r$ & $(V \cdot / \cdot) r_{1}$ & $(V T / T) K r$ & 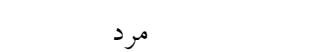 & \\
\hline $\mathrm{df}=1$ & & & & \\
\hline $\mathrm{P}=\cdot / \mathrm{V} \varepsilon$ & & & & \\
\hline نتيجه آزمون تى مستقل: & $(1 \mu / \mu) \varepsilon$ & $(\mathrm{T} / \mathrm{V}) \mathrm{r}$ & كمتر از • ب إ & \multirow{5}{*}{ سن (سال) } \\
\hline $\mathrm{t}=1 / \varepsilon \wedge$ & $(1 \mu / \mu) \varepsilon$ & $(\Gamma / \mu) 1$ & $\mu-\varepsilon$. & \\
\hline $\mathrm{df}=0 . / \mathrm{ra}$ & $(Y \Gamma / \varepsilon) \vee$ & $(Y \backslash / V) \wedge$ & $\varepsilon-0$. & \\
\hline \multirow[t]{2}{*}{$\mathrm{P}=\cdot / / \varepsilon \varepsilon$} & $(0 . \%) 10$ & $(7 \pi / \mu) 19$ & $01-7$. & \\
\hline & $\varepsilon V / 7 T \pm 1 Y / 0 r$ & $01 / V \cdot \pm \Lambda / r \Lambda$ & انحراف معيار 土 ميانخين & \\
\hline نتيجه آزمون دقيق فيشر: & $(1 \mathrm{TV}) 0$ & $(\Gamma / \Gamma) 1$ & مجرد & \multirow{3}{*}{ وضعيت تأهل } \\
\hline \multirow[t]{2}{*}{$\mathrm{P}=\cdot / 190$} & $(\Lambda \mu / r)$ YO & $(q \Gamma / \varepsilon) r \Lambda$ & متأهل & \\
\hline & $(\cdot / \cdot) \cdot$ & $(\Gamma / \Gamma) 1$ & مطلقه & \\
\hline نتيجه آزمون كاى دو: & $(Y \mu / Y) V$ & $(\Gamma / \Gamma) V$ & سواد خواندن و نوشتن & \multirow{3}{*}{ سطح تحصيلات } \\
\hline$X^{2}=r / \cdot \varepsilon \varepsilon \quad d f=r$ & $(0 r / 2) 17$ & $(77 / V) r \cdot$ & دييلم & \\
\hline $\mathrm{P}=\cdot / \pi\urcorner$ & $(r / \mu) V$ & $(1 \cdot / \cdot) r$ & دانشخاهى & \\
\hline نتيجه آزمون دقيق فيشر & $(\varepsilon r / \Gamma) \mid r$ & $(\Pi \mu / \Gamma) 1$. & خوب & \multirow{3}{*}{ وضعيت } \\
\hline \multirow[t]{2}{*}{$\mathrm{P}=\cdot / 177$} & $(0 r / 2) 17$ & $(\varepsilon \tau / V) \mid \varepsilon$ & متوسط & \\
\hline & $(\Gamma / \Gamma) 1$ & $(Y \cdot / \cdot) T$ & ضعيف & \\
\hline نتيجه آزمون دقيق فيش & $(q \Psi / \Gamma) Y \Lambda$ & $(\Lambda \cdot / \cdot) \Gamma \varepsilon$ & شهر & \multirow[t]{2}{*}{ محل زندگى } \\
\hline $\mathrm{P}=\cdot /$ Tor & $(T / V) r$ & $(Y \cdot / \cdot) T$ & 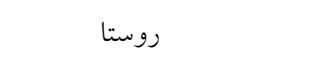 & \\
\hline نتيجه آزمون دقيق فيشر: & $(\bullet / \bullet)$ & $(\Gamma / \Gamma) 1$ & بلى بلى & مصرف مواد \\
\hline $\mathrm{P}=\cdot / 999$ & $(1 \cdot \cdot / \cdot) r \cdot$ & $(97 / V) r q$ & خير & مخدر يا سيگار \\
\hline نتيجه آزمون دقيق فيشر: & $(\Lambda \cdot / \cdot) \Gamma \varepsilon$ & $(\Lambda \neg / \nearrow) \Upsilon\urcorner$ & سرطان ركتوم & \multirow{3}{*}{ علت تعبيه } \\
\hline \multirow[t]{2}{*}{$\mathrm{P}=\cdot / \mathrm{V} \wedge \uparrow$} & $(1 \cdot / \cdot) r$ & $(T / V) r$ & كوليت اولسروز & \\
\hline & $(1 \cdot / \cdot) r$ & $(\mathrm{~T} / \mathrm{V}) \mathrm{r}$ & يولي״ هاى خانو ادكى & \\
\hline نتيجه آزمون دقيق فيشر: & $(7 / V) r$ & $(\Gamma / \varepsilon) 1$ & شيمى درمانى & \multirow{4}{*}{ درمانهاى قبل از } \\
\hline \multirow[t]{3}{*}{$\mathrm{P}=\cdot / \wedge \mu \wedge$} & $(1 \mu / \mu) \varepsilon$ & $(1 \mu / \mu) \varepsilon$ & راديوتر ايى & \\
\hline & $(7 \cdot / \cdot) \backslash \Lambda$ & $(V \cdot / \cdot) r l$ & 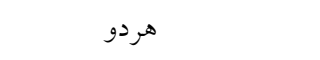 & \\
\hline & $(Y \cdot / \cdot) T$ & $(\mid \Gamma / \mu) \varepsilon$ & هيجكدام & \\
\hline
\end{tabular}


يس از سه هفته بعد از تعبيه CRP reactive protein)

ايلئوستومى، تفاوت معنىدار آمارى داشته است (17 • •

و اين شاخص در گروه كنترل به طور معنىدارى (P=

بالاتر از گروه آزمون بوده است (جدول شماره ؟).
نتايج آزمون تى مستقل نشان دهنده آن بود كه تمامى شاخص هاى بيوشيميايى در دو گروه كترل و آزمون، قبل از مداخله (جدول شماره Y) و همحتِين بس از سه هفته بعد از تعبيه ايلئوستومى (جدول شماره ب) تفاوت معنى

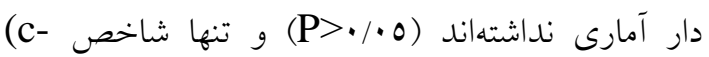

جدول شمار هى ז: توزيع فراوانى شاخصهاى بيوشيميايى در دو تروه كنترل و آزمون، قبل از مداخله و آزمون معنىدارى آنها

\begin{tabular}{|c|c|c|c|c|c|}
\hline نتيجه آزمون & \multicolumn{2}{|c|}{ 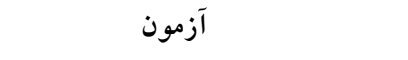 } & \multicolumn{2}{|c|}{ 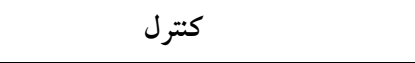 } & شاخص هاى بيوشيميايى \\
\hline آزمون تى & غير طبيعى & طبيعى & غير طبيعى & 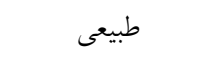 & \\
\hline مستقل & فراوانى (درصد) & فراوانى (درصد) & فراو انى (درصد) & فراوانى (درصد) & قبل از مداحله \\
\hline \multirow{5}{*}{$\begin{array}{l}\mathrm{t}=\cdot / 07 \\
\mathrm{df}=01 \\
\mathrm{P}=\cdot / 0 \mathrm{~V}\end{array}$} & \multirow{4}{*}{$11(r \mathrm{r} / \mathrm{V})$} & \multirow{4}{*}{$19(7 \pi / \pi)$} & \multirow{3}{*}{\multicolumn{2}{|c|}{$0(17 / V)$}} & كلبول هاى سفيد خون \\
\hline & & & & & Normal $=(4.1-$ \\
\hline & & & & & $\left.10.1 \times 1000 / \mathrm{mm}^{3}\right)$ \\
\hline & & & \multicolumn{2}{|c|}{$r / \Lambda-1 \cdot / / \Lambda$} & بيشينه-كمينه \\
\hline & \multicolumn{2}{|c|}{$0 / 2 \cdot \pm 1 / 10$} & $0 / 7$ & $\pm 1 / 9 \mathrm{r}$ & انحراف معيار \ ميانخين \\
\hline \multirow{3}{*}{$\begin{array}{l}\mathrm{t}=1 / \cdot \wedge \\
\mathrm{df}=\Delta \wedge\end{array}$} & \multirow{3}{*}{$r \cdot(77 / V)$} & \multirow{3}{*}{$1 \cdot(\pi / \mu)$} & \multirow{2}{*}{$11(7 \cdot / \cdot)$} & \multirow{3}{*}{$1 Y(\varepsilon \cdot / \cdot)$} & تعدادكل لنفوسيتها \\
\hline & & & & & Normal $=(25-35 \%)$ \\
\hline & & & & & بيشينه-كمينه \\
\hline $\mathrm{P}=\cdot / \mathrm{\uparrow} \wedge$ & \multicolumn{2}{|c|}{$r / / r T \pm \Lambda / r \varepsilon$} & \multicolumn{2}{|c|}{$r r / r q \pm T / r V$} & انحراف معيار \ ميانخين \\
\hline \multirow{4}{*}{$\begin{array}{l}\mathrm{t}=1 / 7 \\
\mathrm{df}=\Delta \wedge \\
\mathrm{P}=\cdot / 11\end{array}$} & \multirow{3}{*}{$1 \varepsilon(\varepsilon \tau / V)$} & \multirow{3}{*}{$17(0 r / r)$} & \multirow{2}{*}{$9(r \cdot / \cdot)$} & \multirow{3}{*}{$r I(V \cdot / \cdot)$} & همو كلوبين: \\
\hline & & & & & Normal $=(12-16 \mathrm{~g} / \mathrm{dl})$ \\
\hline & & & & & بيشينه -كمينه \\
\hline & \multicolumn{2}{|c|}{$I T / T O \pm I / \Lambda r$} & \multicolumn{2}{|c|}{$|r / \cdots \pm 1 / \lambda|$} & انحراف معيار \ ميانكين \\
\hline \multirow{4}{*}{$\begin{array}{l}\mathrm{t}=\cdot / 01 \\
\mathrm{df}=0 \wedge \\
\mathrm{P}=\cdot / 7\end{array}$} & \multirow{2}{*}{\multicolumn{2}{|c|}{$19(97 / V)$}} & \multirow[t]{2}{*}{$r(\mathrm{~T} / \mathrm{V})$} & \multirow[t]{2}{*}{$r \Lambda(q \Gamma / \mu)$} & آلبومين: \\
\hline & & & & & Normal $=(3.5-5.2 \mathrm{~g} / \mathrm{dl})$ \\
\hline & \multicolumn{2}{|c|}{$r / r-0$} & \multicolumn{2}{|c|}{$r / N-0 / 0$} & بيشينه -كمينه \\
\hline & $\multicolumn{2}{|c|}{/ \pi} \pm \cdot / \varepsilon)$ & \multicolumn{2}{|c|}{$\varepsilon / \varepsilon 1 \pm \cdot / \varepsilon r$} & انحراف معيار \ميانخين \\
\hline$t=\cdot / 90$ & $1(\Gamma / \mu)$ & $r 9(97 / V)$ & - & $r \cdot(1 \cdot \cdot / \cdot)$ & 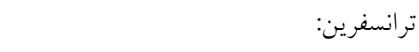 \\
\hline $\mathrm{df}=\Delta \wedge$ & & & & & Normal $=(160-340 \mathrm{mg} / \mathrm{dl})$ \\
\hline $\mathrm{P}=\cdot / \mu \varepsilon$ & & $-r_{\varepsilon}$ & & $-\mu$. & بيشينه -كمينه \\
\hline & rorl & $\pm \sum r / 0 r$ & $T \sum Y / T$ & $\pm r V / T h$ & انحراف معيار \ميانخين \\
\hline$t=-1 / r$ & . & $r \cdot(1 \cdot . / \cdot)$ & . & $r \cdot(1 . . \cdot \cdot)$ & CRP (c-reactive protein) \\
\hline $\mathrm{df}=\Delta \wedge$ & & & & & Normal= (<10 mg/dl) \\
\hline$P=. / 19$ & & 1. & & $-\Lambda$ & بيشينه-كمينه \\
\hline te & & $\pm r \mu r$ & $r / 77$ & $\pm 1 / 07$ & انحراف معيار \ميانخين \\
\hline$t=1 / 21$ & $\operatorname{lr}(\varepsilon \cdot / \cdot)$ & $1 \Lambda(7 \cdot / \cdot)$ & $V(T / / \Gamma)$ & $r \mu(V T / V)$ & 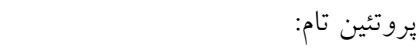 \\
\hline $\mathrm{df}=\Delta \wedge$ & & & & & Normal $=(6.6-8.8 \mathrm{~g} / \mathrm{dl})$ \\
\hline $\mathrm{P}=\cdot / 17$ & $0 / 2-1$ & & $0 / \Lambda-\Lambda)$ & & بيشينه -كمينه \\
\hline & $\mathrm{T} / \mathrm{V} \varepsilon \pm$ & & T/9V. \pm & & انحراف معيار \ميانكين \\
\hline
\end{tabular}


جدول شمارهى سّ: توزيع فراوانى شاخصهاى بيوشيميايى در دوكروه كنترل و آزمون، سه هفته بعد از تعبيه ايلئوستومى و آزمون

معنى دارى آنها سماري

\begin{tabular}{|c|c|c|c|c|c|}
\hline نتيجه آزمون & \multicolumn{2}{|c|}{ آزمون } & \multicolumn{2}{|c|}{ كنترل ل } & \multirow{2}{*}{ سه هفته بعد از تعبيه } \\
\hline آزمون تى & غير طبيعى & طبيعى & غير طبيعى & طبيعى & \\
\hline مستقل & فراوانى (درصد) & فراوانى (درصد) & فراوانى (درصد) & فراوانى (درصد) & ايلئوستومى إل \\
\hline$t=1 / 2 r$ & $r(T / V)$ & $r \Lambda(q r / r)$ & $0(1 \mathrm{~T} / \mathrm{V})$ & ro $(\Lambda \mu \mu)$ & كلبول هاى سفيد خون \\
\hline $\mathrm{df}=0 \wedge$ & & & & & $\begin{array}{l}\text { Normal }=(4.1-10.1 \times \\
\left.1000 / \mathrm{mm}^{3}\right)\end{array}$ \\
\hline
\end{tabular}

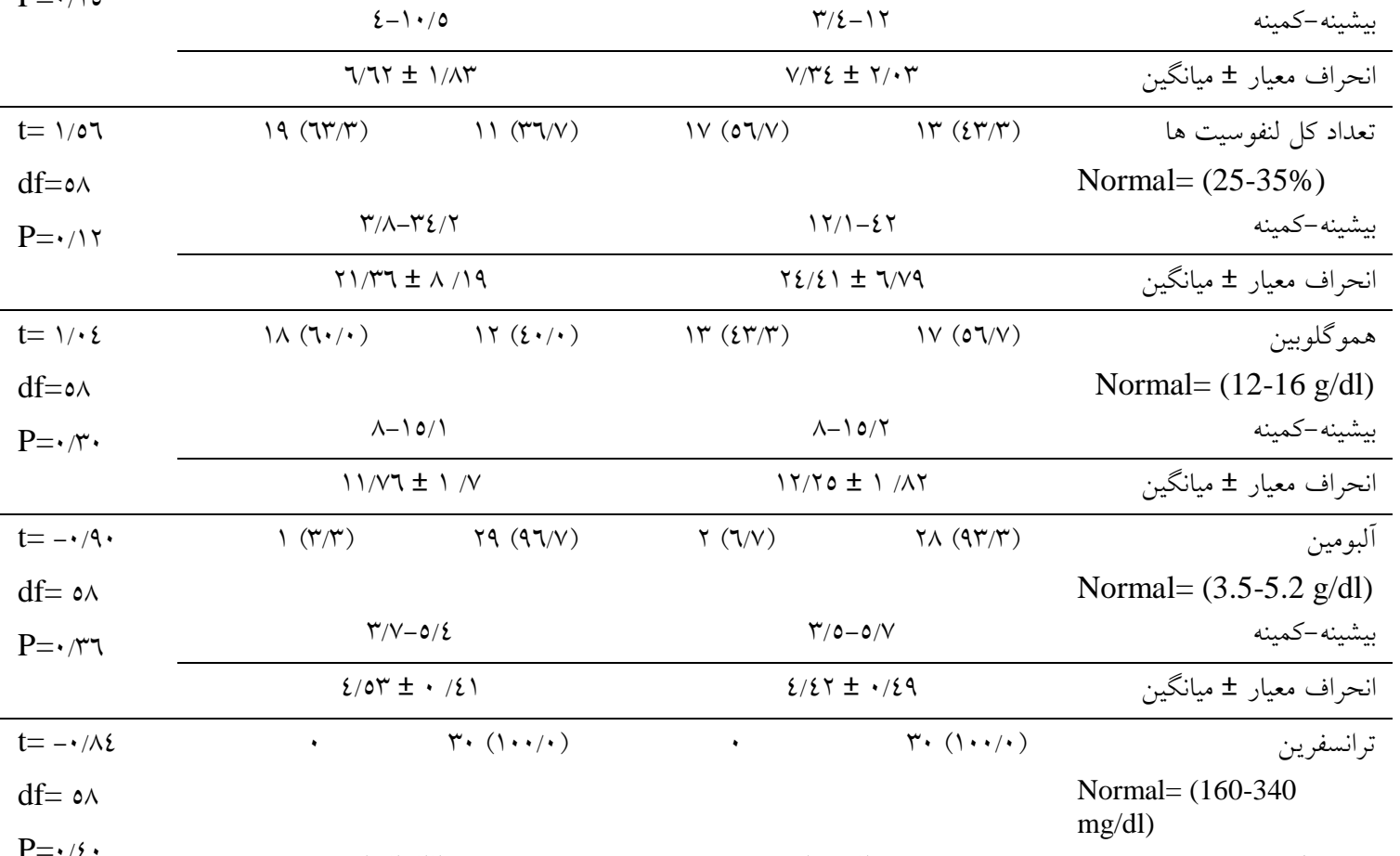

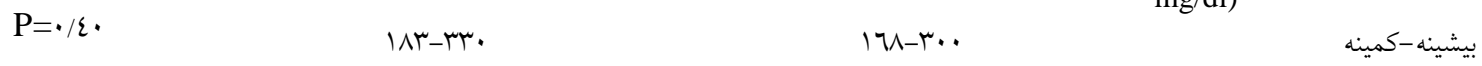

\begin{tabular}{|c|c|c|c|c|c|}
\hline \multirow{4}{*}{$\begin{array}{l}\mathrm{t}=r / \varepsilon \wedge \\
\mathrm{df}=0 \wedge \\
\mathrm{P}=\cdot / \cdot 17\end{array}$} & \multicolumn{2}{|c|}{$r Y \mathrm{O} / \mathrm{TV} \pm\{\tau / 7\rceil$} & \multicolumn{2}{|c|}{$r Y T / T I M N / r V$} & \multirow{2}{*}{ 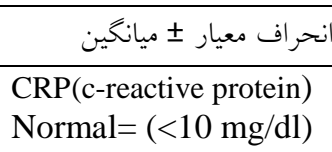 } \\
\hline & $V(T / / \mu)$ & $r r(V T / V)$ & $10(0 . / \%)$ & $10(0 . \%)$ & \\
\hline & \multicolumn{2}{|c|}{$r-1 r$} & \multicolumn{2}{|c|}{$r-r}$. & بيشينه -كمينه \\
\hline & \multicolumn{2}{|c|}{$V / 77 \pm r / \cdot 1$} & \multicolumn{2}{|c|}{$1 \cdot / r \pm \varepsilon / N \mu$} & انحراف معيار 土 ميانخين \\
\hline$t=-1 / 0$ & $\varepsilon(1 \mu / \mu)$ & $r\urcorner(\Lambda \neg / V)$ & $9(\Gamma \cdot / \cdot)$ & $r l(V \cdot / \cdot)$ & يروتئين تام \\
\hline $\mathrm{df}=0 \wedge$ & & & & & Normal $=(6.6-8.8 \mathrm{~g} / \mathrm{dl})$ \\
\hline \multirow[t]{2}{*}{$\mathrm{P}=\cdot / 11$} & \multicolumn{2}{|c|}{$V / T-\Lambda / O$} & \multicolumn{2}{|c|}{$0 / 7-1 / 0$} & بيشينه -كمينه \\
\hline & \multicolumn{2}{|c|}{$V / T V \pm \cdot / 09$} & \multicolumn{2}{|c|}{$V / \cdots \pm \cdot / 79$} & انحراف معيار 土 ميانخين \\
\hline
\end{tabular}

كروه كنترل داشتهاند و CRP (c-reactive protein) در گروه كترل افزايش معنى دارى داشته است (جدول

$$
\text { شماره ع) (ع) }
$$

نتايج آزمون تى مستقل تغييرات شاخص هاى بيوشيميايى

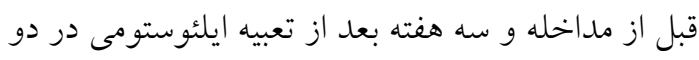

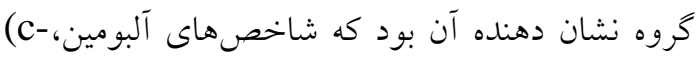
CRP reactive protein)

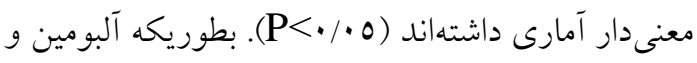

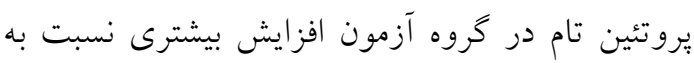


جدول شماره ع: جدول تغييرات قبل از مداخله و سه هفته بعد از تعبيه ايلئوستومى شاخصهاي بيوشيميايى در دو تروه كنترل و

آزمون جدون

\begin{tabular}{|c|c|c|c|}
\hline 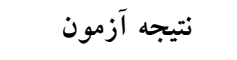 & 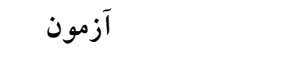 & 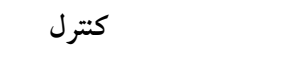 & \multirow[t]{2}{*}{ شاخص هاى بيوشيميايى } \\
\hline آزمون تى مستقل & انحراف معيار 土 ميانخين & انحراف معيار 土 ميانخين & \\
\hline $\mathrm{t}=1 / 7 \mathrm{~V}$ & $|/ r| \pm 1 / \cdot r$ & $1 / 77 \pm 1 / .0$ & كلبولهاى سفيد خون \\
\hline $\mathrm{df}=\Delta \wedge$ & & & Normal $=(4.1-10.1 \times$ \\
\hline $\mathrm{P}=\cdot / 1$ & & & $\left.1000 / \mathrm{mm}^{3}\right)$ \\
\hline$t=1 / \mu\urcorner$ & $\cdot / \Omega \pm r / O r$ & $1 / 1 r \pm 1 / V \varepsilon$ & تعداد كل لنفوسيتها \\
\hline $\mathrm{df}=0 \wedge$ & & & Normal $=(25-35 \%)$ \\
\hline \multicolumn{4}{|l|}{$\mathrm{P}=\cdot / \mathrm{V}$} \\
\hline & $\cdot / \varepsilon \wedge \pm \cdot / N r$ & $\cdot / V 0 \pm \cdot / V 7$ & 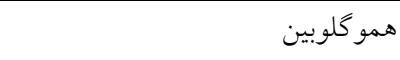 \\
\hline $\mathrm{df}=\Delta \wedge$ & & & Normal $=(12-16 \mathrm{~g} / \mathrm{dl})$ \\
\hline \multicolumn{4}{|l|}{$\mathrm{P}=\cdot / \mathrm{V}$} \\
\hline$t=r / \varepsilon$. & $\cdot / / V \pm \cdot / \Gamma \Lambda$ & •/ & آلبومين \\
\hline $\mathrm{df}=\Delta \wedge$ & & & Normal $=(3.5-5.2 \mathrm{~g} / \mathrm{dl})$ \\
\hline \multicolumn{4}{|l|}{$\mathrm{P}=\cdot / \cdot \mathrm{r}$} \\
\hline$t=\cdot / T$ & $17 / 7 r \pm r V / r$. & $10 / 9 r \pm 17 / 0$ & ترانسفرين \\
\hline $\mathrm{df}=\varepsilon \varepsilon / \Gamma$ & & & Normal= $(160-340 \mathrm{mg} / \mathrm{dl})$ \\
\hline \multicolumn{4}{|l|}{$\mathrm{P}=\cdot / 9$} \\
\hline $\begin{array}{l}\mathrm{t}=\mathrm{r} / \mathrm{rv} \\
\mathrm{df}=\Delta \wedge\end{array}$ & $\varepsilon / \mu \pm \Psi / \ell \varepsilon$ & $V / 0 \pm \varepsilon / \varepsilon$. & $\begin{array}{l}\text { CRP(c-reactive protein }) \\
\text { Normal }=(<10 \mathrm{mg} / \mathrm{dl})\end{array}$ \\
\hline \multicolumn{4}{|l|}{$\mathrm{P}=\cdot / \cdot r$} \\
\hline $\mathrm{t}=\varepsilon / 0$ & $\cdot / 0 r \pm \cdot / 2 r$ & $\cdot / \cdot r \pm \cdot / 2 r$ & يروتئين تام \\
\hline $\mathrm{df}=\Delta \wedge$ & & & Normal= $(6.6-8.8 \mathrm{~g} / \mathrm{dl})$ \\
\hline $\mathrm{P}<\cdot / \cdot \cdot 1$ & & & \\
\hline
\end{tabular}

دار آمارى نداشتهاند. CRP (c-reactive protein)

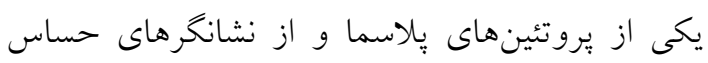

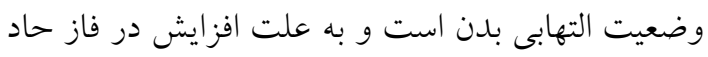

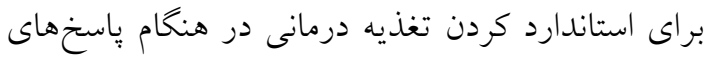
التهابى مىتوان از آن استفاده كرد (TrTrآ.

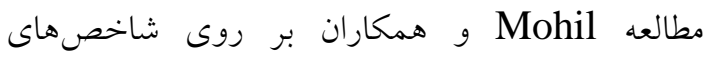
بيوشيميايى شش هفته بعد از تعبيه ايلئوستومى نشان داد

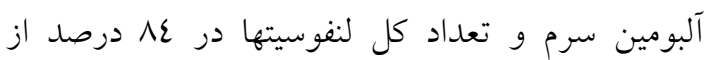
بيماران كمتر از حد نرمال بود و بيش از نيمى از بيماران

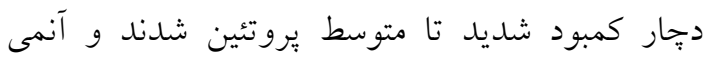
داشتند، عليرغم مصرف كالرى كافى طبق معادله هريس بنديك (harris-Benedict Equation)، كه

\section{بحث و نتيجه كيرى} اين مطالعه با هدف بروسى تيجى تأثير آموزش تغذيه مبتنى بر

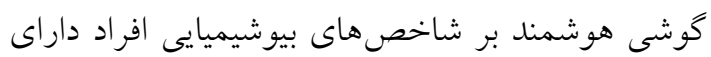

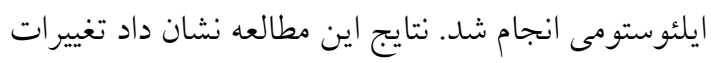

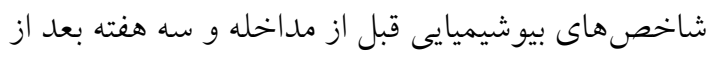
تعبيه ايلئوستومى در دو گروه در شاخصهاى نداى آلبومين، CRP (c-reactive protein)

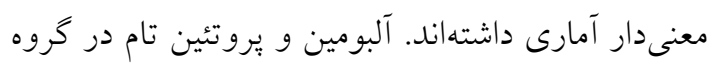
آزمون و CRP (c-reactive protein) در كروه كنترل افزايش بيشترى داشتهاند. ساير شاخصهاى بيوشيميايى بررسى شده؛ كلبولهاى سفيد خون، تعداد

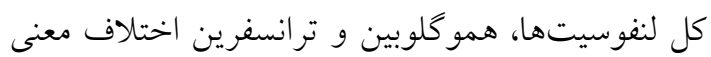


اى از طريق تلفنهاى همراه در بيماران كولستومى نشان

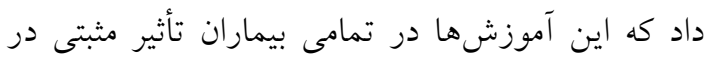

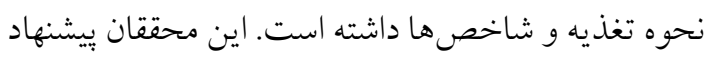
دادند استفاده از برنامه كاربردى (application) ييام

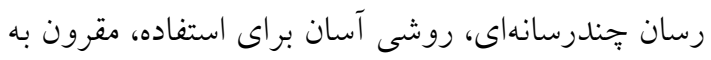

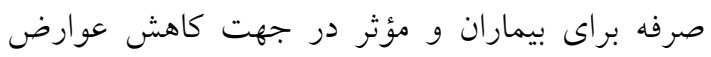
كولستومى و افزايش دانش و آكَاهى بيمار و مراقبين آنها

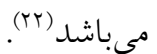
آموزش به بيماران و خانواده مىتواند يكى از مؤثرترين مداخلات، جهت ارتقا توانايى خود مراقبتى و اجراى صحيح رفتارهاى خود مراقبتى بيماران باشد، كه سبب نوانب

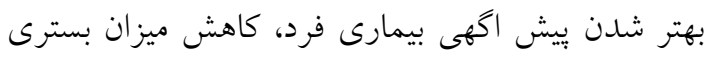

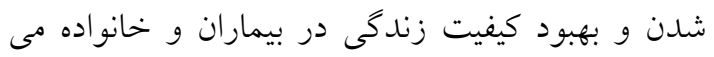

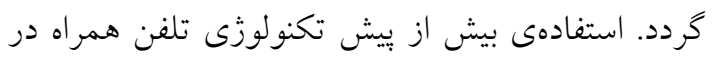

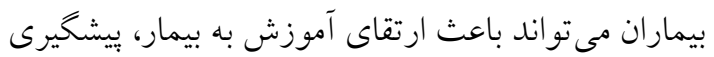

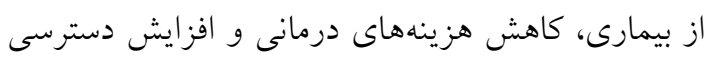

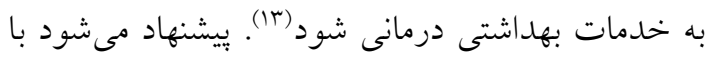

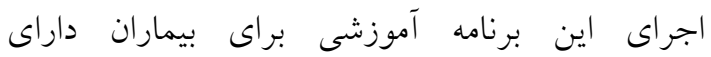

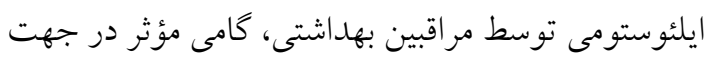
ارتقاء شاخصهاى بيوشيميايى اين بيماران برداشته شود برد

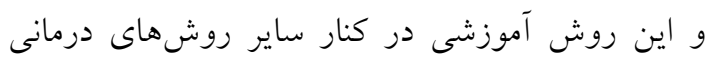

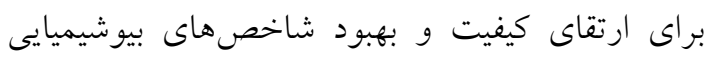

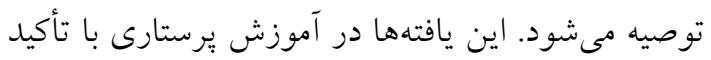
بر آموزش تغذيه، جهت ارائه مراقبتهاى بيمار - محور براى دانشجويان و برستاران مىتو اند مفيد باشد. از محدوديتهاى اين مطالعه مىتوان به كسب اطلاعات

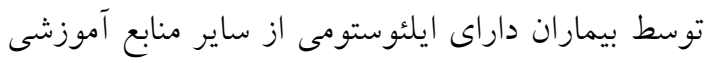

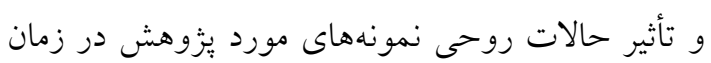
آموزش، خصوصيات شخصيتى افراد در بذّيرش موارد

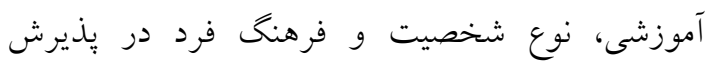
محتواى آموزشى اشاره كرد. با توجه به نتيجه مطالعه حاضر، گر جّهـ از نظر آمارى

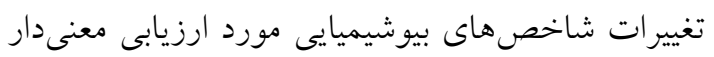
بودند ولى از نظر كلينيكى با توجه به تغييرات ناجيز
متابوليسم پيايه را بر اساس كيلوكالرى مصرفى روزانه

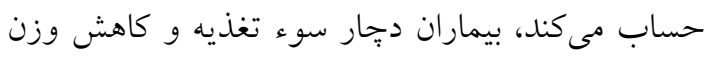

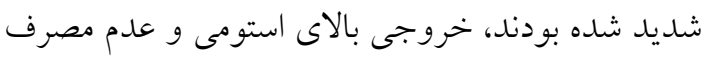

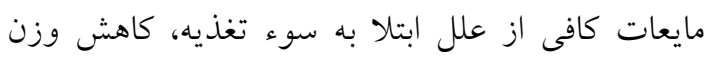

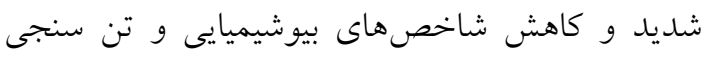

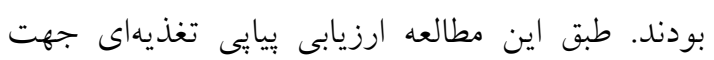

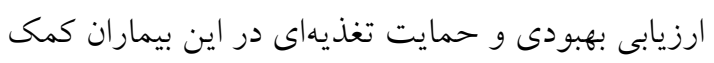

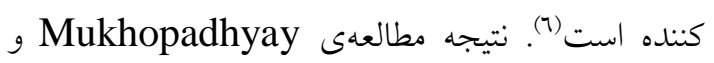
همكاران بر روى شاخصهاى بيوشيميايى در طى سه ماه

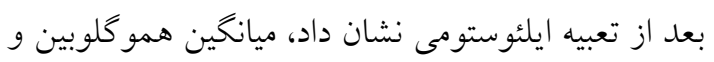

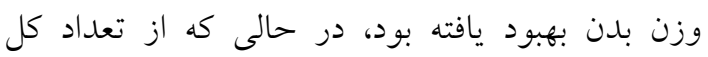

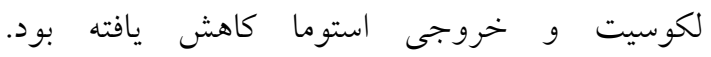
الكتروليتهاى سرم كمى افزايش يافته بود. كل بروتئين

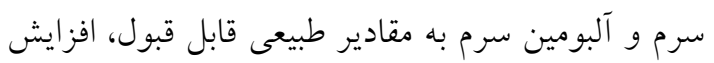

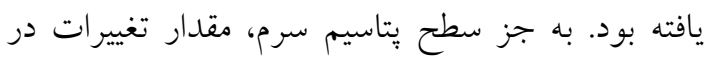

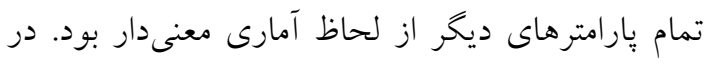

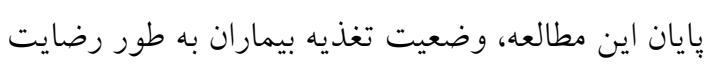

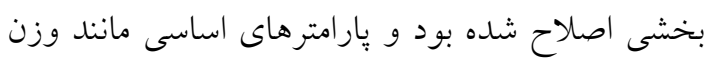

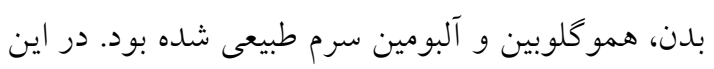

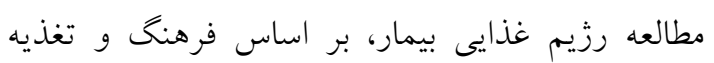

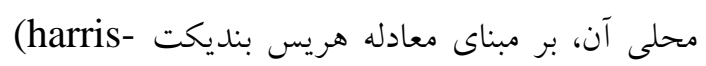
طراحى شده بود (r). نتايج مطالعات نشان مىدهد كه كمبودهاى تغذيهاى علت اصلى كاهش توليد همو كلوبين و اريتروسيتها مى باشند.

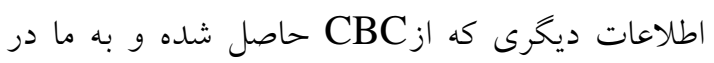
ارزيابى علل غير تغذيهاى كم خونى كمك مى كند،

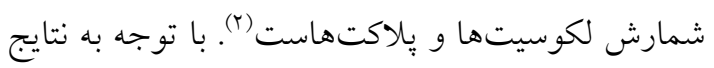

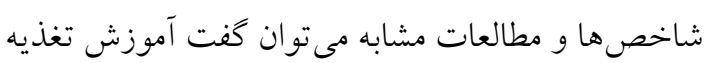

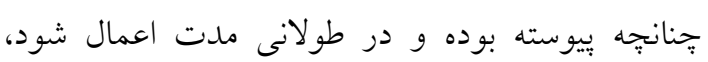

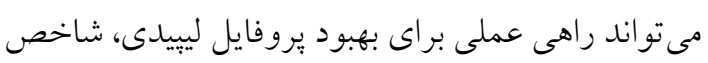

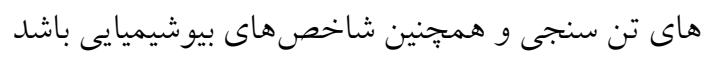
و از بروز عوارض ثانويه بيمارى بيشكيرى كند (11).

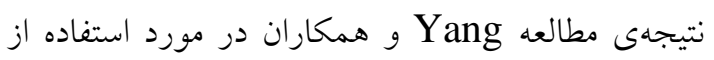

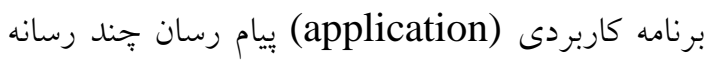




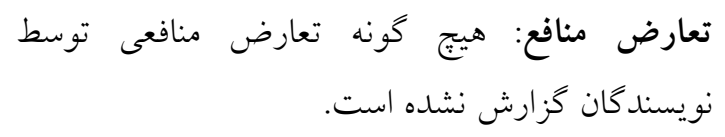

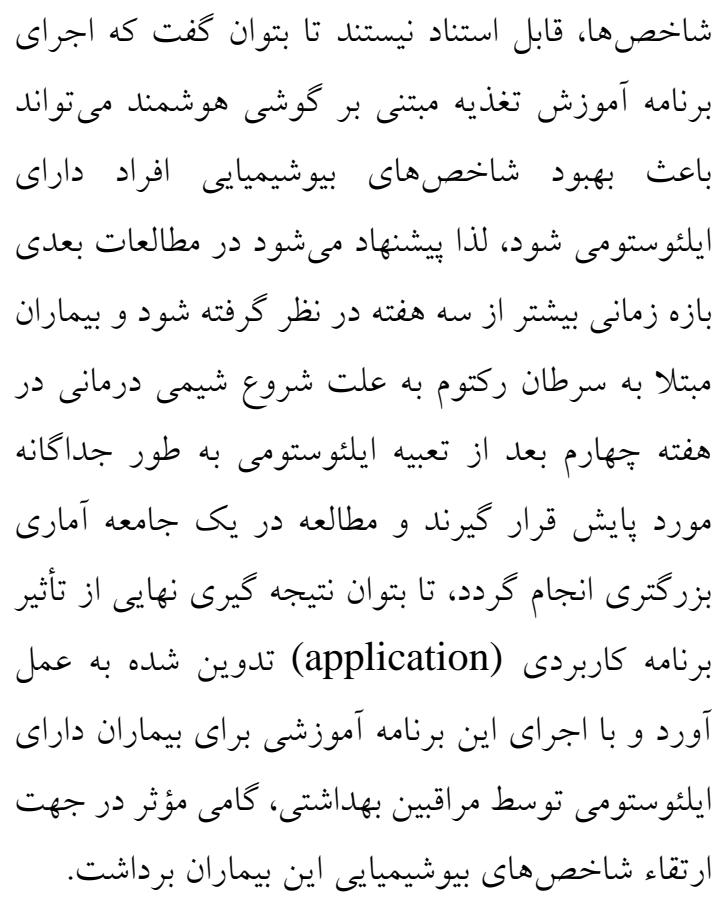

\section{References}

1. Brunner LS. Brunner \& Suddarth's textbook of medical-surgical nursing. Lippincott Williams \& Wilkins; 2017.

2. Mahan LK, Raymond JL. Krause's food \& the nutrition care process-e-book. Elsevier Health Sciences; 2016 May 17.

3. Mukhopadhyay A, Maity D, Dey R, Choudhury KB, Das G, Bhattacharya U. Can Postoperative Nutrition be Favourably Maintained by Oral Diet in Patients with Emergency Temporary Ileostomy? A Tertiary Hospital Based Study. Journal of Clinical and Diagnostic Research: JCDR. 2015;9(12):PC04.

4. LeMone P, Burke K, Dwyer T, Levett-Jones T, Moxham L, Reid-Searl K. Medical-surgical nursing: Pearson Higher Education AU. National Library of Australia: Pearson. 2013;54.

5. Akbulut G. Nutrition in stoma patients: a practical view of dietary therapy. International Journal of Hematology and Oncology. 2011;28(4):061-6.

6. Mohil RS, Narayan N, Sreenivas S, Singh N, Bansal A, Singh GJ. Challenges of Managing Emergency Ileostomy: Nutrition-A Neglected Aspect. ISRN Emergency Medicine. 2012 $4 ; 2012$.

7. Paquette IM, Solan P, Rafferty JF, Ferguson MA, Davis BR. Readmission for dehydration or renal failure after ileostomy creation. Dis Colon Rectum. 2013;56(8):974-9.

8. Masoudi R, Alhani F, Moghadassi J, Ghorbani M. The effect of family-centered empowerment model on skill, attitude, and knowledge of multiple sclerosis caregivers. Journal of Birjand University of Medical Sciences. 2010;17(2):87-97. [Persian]

9. Valentine F. Effective Leadership and Management in Nursing. Journal of Clinical Nursing. 2008;17(6):840-.

10. Papzan A, Soleymani A. Comparing Cell Phone-Based and Traditional Lecture-Based Teaching Methods'effects on Agricultural Students'learning. 2010. Information and Communication Technology in Educational Sciences. 2010 ;1(1):55-65. [Persian]

11. Nikroo H, Nematy M, Sima H, AttarzadeHosseini S, Pezeshki M, Esmaeilzadeh A, Vossoughinia H, MohammadianDamasaki M. Therapeutic effects of aerobic exercise and lowcalorie diet on nonalcoholic steatohepatitis. Govaresh. 2013;17(4):245-53. [Persian]

12. Jo S, Park H. Development and evaluation of a smartphone application for managing gestational diabetes mellitus. Healthcare informatics research. 2016;22(1):11-21.

13. Doswell WM, Braxter B, Dabbs AD, Nilsen W, Klem ML. mHealth: Technology for nursing practice, education, and research. J Nurs Educ Pract. 2013;3(10):99. 
14. Zaidan S, Roehrer E. Popular mobile phone apps for diet and weight loss: a content analysis. JMIR mHealth and uHealth. 2016;4(3):e80.

15. Cho MJ, Sim JL, Hwang SY. Development of smartphone educational application for patients with coronary artery disease. Healthcare informatics research. 2014;20(2):117-24.

16. Rouholiman D, Gamble JG, Dobrota SD, Encisco EM, Shah AG, Grajales III FJ, Chu LF. Improving Health-Related Quality of Life of Patients With an Ostomy Using a Novel Digital Wearable Device: Protocol for a Pilot Study. JMIR research protocols. 2018;7(3):e82.

17. Coughlin SS, Whitehead M, Sheats JQ, Mastromonico J, Hardy D, Smith SA. Smartphone applications for promoting healthy diet and nutrition: a literature review. Jacobs journal of food and nutrition. 2015;2(3):021.

18. Hurt K, Walker RJ, Campbell JA, Egede LE. mHealth interventions in low and middle-income countries: a systematic review. Glob J Health Sci. 2016;8(9):183.

19. Akter M, Uddin MS. Android-based Diabetes Management System. Int J Comput Appl. 2015;110(10):5-9.

20. Holtz B, Lauckner C. Diabetes management via mobile phones: a systematic review. Telemedicine and e-Health. 2012;18(3):175-84.

21. Purohit MR, Sharma M, Rosales-Klintz S, Lundborg CS. 'Multiple-test'approach to the laboratory diagnosis of tuberculosis-perception of medical doctors from Ujjain, India. $B M C$ infectious diseases. 2015;15(1):322.

22. Yang $\mathrm{CH}$, Maher JP, Conroy DE. Implementation of behavior change techniques in mobile applications for physical activity. Am j Prev Med. 2015;48(4):452-5. 